\title{
Thermal Energy Performance Simulation of a Residential Building Retrofitted with Passive Design Strategies: A Case Study in Mexico
}

\author{
Ana Paola Vargas and Leon Hamui * (1)
}

Citation: Vargas, A.P.; Hamui, L.

Thermal Energy Performance

Simulation of a Residential Building Retrofitted with Passive Design Strategies: A Case Study in Mexico. Sustainability 2021, 13, 8064. https:// doi.org/10.3390/su13148064

Academic Editor:

Ali Bahadori-Jahromi

Received: 6 May 2021

Accepted: 21 June 2021

Published: 19 July 2021

Publisher's Note: MDPI stays neutral with regard to jurisdictional claims in published maps and institutional affiliations.

Copyright: (c) 2021 by the authors. Licensee MDPI, Basel, Switzerland. This article is an open access article distributed under the terms and conditions of the Creative Commons Attribution (CC BY) license (https:// creativecommons.org/licenses/by/ $4.0 /)$.
Facultad de Ingeniería, Universidad Anáhuac México, Avenida Universidad Anáhuac 46, Col. Lomas Anáhuac, Huixquilucan 52786, Estado de México, Mexico; ana.vargasch@anahuac.mx

* Correspondence: leon.hamui@anahuac.mx; Tel.: +52-55-5627-0210

\begin{abstract}
High energy consumption as a result of an inefficient design has both economic and environmental repercussions throughout the life cycle of a building. In Mexico, the residential sector is the third-largest final energy consumer, therefore improving the performance of existing buildings is considered an effective method in achieving energy savings. Moreover, in Mexico warm climate regions predominate, which impacts energy consumption. This article examines a linked, singlefamily house located in the hot-humid climate city of Villahermosa, Tabasco (México). DesignBuilder software was used to conduct the thermal energy performance simulation of the existing building (base case) and to evaluate the energy-saving potentials by implementing different passive design strategies. As a result, the annual electricity consumption of the base case decreased a maximum of $2.0 \%$ with the passive design strategy in exterior windows, $4.9 \%$ in walls and, $13.7 \%$ reduction in roofs, the latter being the enclosure with the greatest reduction achieved. Nevertheless, a final adaptation proposal with the passive design strategies, whose results represented the highest energy savings, accomplished a total reduction of $23.5 \%$ with a payback period of 5.8 years.
\end{abstract}

Keywords: passive design strategies; hot-humid climate; thermal energy performance simulation; energy efficiency

\section{Introduction}

In the last decade, society has increased energy consumption to carry out its daily activities, and the proper operation of its production processes, both of which are essential to enhance the social and economic well-being of a country [1]. The International Energy Agency (IEA) reports that the global primary energy demand increased by $2.3 \%$ in 2018, the largest annual increase since 2010, and well above those in 2015 and 2016. Moreover, similarly to primary energy demand, final energy demand also increased in 2018, by $2.2 \%$ [2]. The countries that registered the highest energy consumption were: China (20.71\%), the United States (16.04\%), India (6.10\%), Russia (5.18\%), and Japan (2.85\%) [1].

The residential sector contributes a substantial portion of global energy consumption and greenhouse gas (GHG) emissions in every country. This sector is responsible for more than $40 \%$ of global energy used and for as much as $33 \%$ of global GHG emissions $[3,4]$. According to the Energy Information Administration (EIA), it is projected that the energy consumed in this sector will increase by 65\% between 2018 and 2050 [5].

In Mexico, the residential sector is the third-largest final energy consumer $[1,6,7]$, representing $14 \%$ of total final energy consumption, while in terms of electrical energy consumption, it accounts for $23 \%$ of the national total, and represents $17 \%$ of total National GHG emissions [1,8]. Therefore, the implementation of energy efficiency actions and GHG mitigation is of great importance and should be studied in detail for this country. Although there have been significant improvements in the energy efficiency for the residential sector; these efforts have achieved a greater impact in temperate climate regions than in 
warm climate regions. This is because the most effective public policies in warm regions have mainly focused on the energy efficiency of electrical appliances, leaving aside the building design, which accounts for the highest energy consumption for these types of regions $[9,10]$. Moreover, since in Mexico the warm climate regions predominate, due to its geographical position, the thermal performance of a building has a great impact on the energy demand in this sector [9]. The Federal Electricity Commission (CFE, by its acronyms in Spanish), calculates that in Mexico, a user in a warm climate region consumes twice as much electricity as one in a temperate climate [10].

According to the US Green Building Council (USGBC), it is estimated that today, on average, green buildings can reduce energy consumption by $30 \%$. There are several features which can make a building green, one of them is an efficient use of energy [11], where the achievement of an adequate level of comfort is accomplished mainly through the implementation of passive design systems, which take full advantage of the building environment climatic conditions [12-18]. An excellent passive building design can significantly decrease the energy consumption in a building by reducing heating/cooling loads through the building envelope (walls and fenestration) [19-21], which have been proven to be an extremely important influence on thermal performance [22-25].

Mexico has the mandatory standard NOM-020-ENER-2011 (abbreviated as NOM020) [26] which limits heat gains through the envelope for residential buildings; and the voluntary standard NMX-C-460-ONNCCE-2009 (abbreviated as NMX-C-460) [27] which recommends thermal resistance values (R-value) for envelopes by thermal region [28], but the implementation of efficiency policies in the building sector is complicated due to the devolution of policy responsibility to local jurisdictions. In addition, local municipalities do not have the knowledge or proper technical skills to fully understand the energy deficiencies of buildings and proper funding is needed for the implementation of the existing normativity. An additional problem is that most municipal building standards fail to require the application of NOM-020, even though this federal regulation is currently active and mandatory, and since the local municipalities are the entities that grant building permits, NOM-020 is generally ignored [29]. Furthermore, according to the SmartMarket Report, in Mexico slightly more than one quarter (27\%) of people do most of their projects green [30]. Therefore, using building energy modeling (BEM) to compare energy-efficiency options can be a crucial tool to direct design decisions prior to construction or even to optimize energy operation, or explore retrofit opportunities in existing building projects that can generate both economic, social, and environmental benefits. It can be used to perform a detailed analysis of a building's energy use and energy-using systems, to compare project efficiency options, comply with codes or green building certification requirements, optimize on-going energy costs, and inform actual performance [31]. The economic advantages due to the application of energy-saving measures for buildings can be classified into direct or indirect ones. The first depend on the reduction of energy consumption, and are directly evident in the management costs (lowering the costs on the energy bill). By contrast, the latter are more difficult to detect, they consist of an increase in the asset market value due to the improvement of its energy rating $[32,33]$.

However, improving the performance of existing buildings is as critical in achieving the goals of green buildings as the construction of new green buildings, if not more so [30]. According to the National Institute of Statistics and Geography (INEGI, by its acronyms in Spanish), in the country, this sector comprises approximately a total of 35 million inhabited housing units with an average of 3.7 occupants per dwelling [34]. However, it is expected that, by the year 2030, 28\% of households in Mexico will require complete or partial improvements, which represent a great opportunity to improve the energy efficiency in this sector [35]. Therefore, the present study takes an existing residential building located in a hot-humid climate of Mexico, specifically the city of Villahermosa, Tabasco, to generate a proposal with passive design strategies, supported by building energy modelling, to improve the usage of energy and consequently the reduction of electricity consumption. 
This may establish a replicability criterion for the residential sector with similar climatic regions within the country.

\section{Methods}

A thermal energy performance simulation of a case study building in Villahermosa, Tabasco (Mexico) was conducted using DesignBuilder software [36]. This analysis aimed to stand for the effect that the passive design strategy has on the energy consumption of the building studied in this case.

\subsection{The Case Study}

The residential building studied (base case) is a linked, single-family house located in the city of Villahermosa, Tabasco (México). The total building surface area is $198 \mathrm{~m}^{2}$ and consists of a total of 3 floors with 4 bedrooms, a study room, a living-dining room, a kitchen, an office, and 4 bathrooms. As shown in Figure 1, the main façade of the building is orientated to the west.

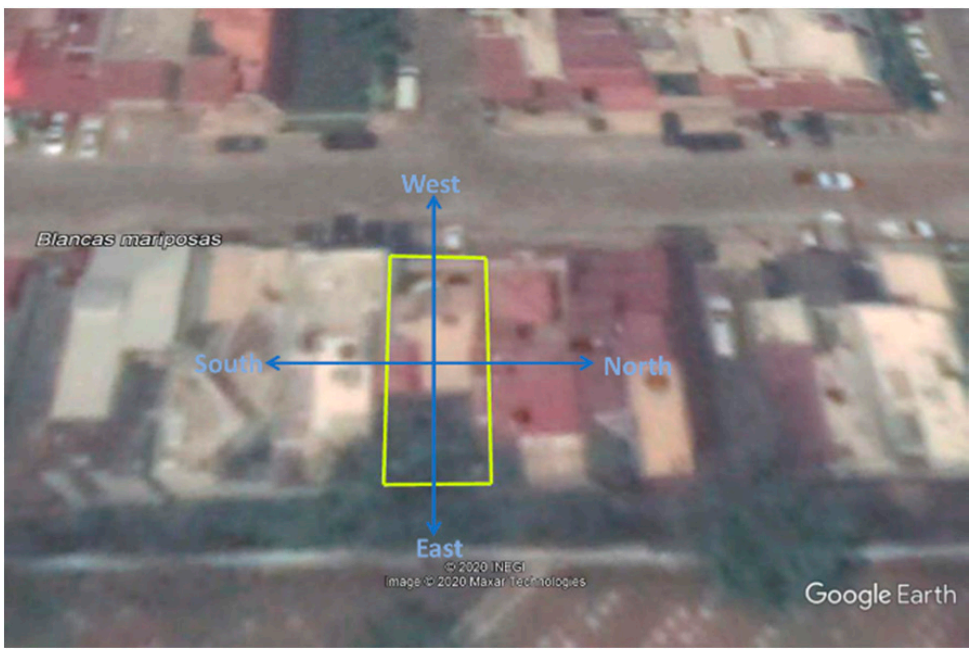

(a)

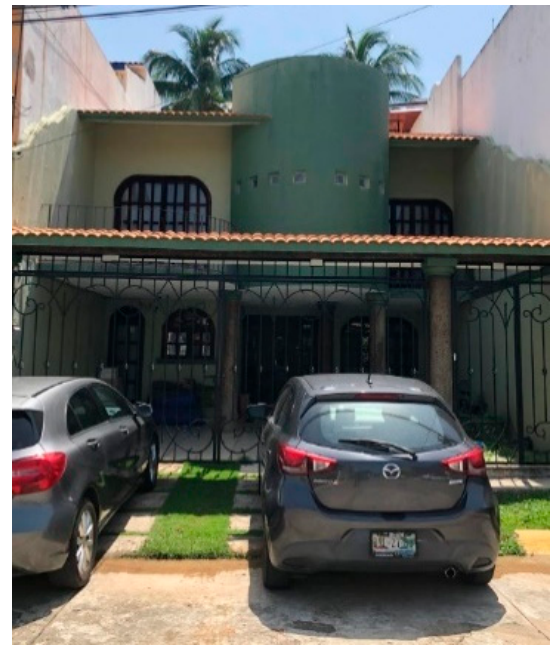

(b)

Figure 1. This is a (a) Building location in Villahermosa, Tabasco (Mexico); (b) The main façade of the residential building.

\subsubsection{Weather Data}

The weather data of Villahermosa, Tabasco was extracted from Meteonorm software [37] and added to Designbuilder software. These site-specific weather data were required to perform an accurate energy-consumption assessment of the residential building.

The annual weather data is a critical input for building energy modeling. Therefore, in order to corroborate that the EPW (EnergyPlus Weather Data) file introduced in the software was accurate, the National Meteorological Service (SMN, by its acronyms in Spanish) weather files [38] and the NASA Langley Research Center (LaRC) POWER Project funded through the NASA Earth Science/Applied Science Program files [39] were consulted. Table 1 shows the main climatic parameters of Villahermosa, Tabasco, including the temperature, relative humidity, precipitation, and wind speed.

\subsubsection{Building Data}

A field study was carried out to investigate the building's data (construction materials, occupancy, lighting loads, HVAC controls, plug loads, and operation schedules). The surface mass, the U-value, and solar factors (of the fenestration only) of the residential building (base case) are shown in Tables 2 and 3. It is worth mentioning that the structural elements of the thermal envelope and interior partitions were typical for this type of buildings in Mexico [40]. 
Table 1. Climatic parameters of Villahermosa, Tabasco, 2008 to 2018.

\begin{tabular}{ccc}
\hline \multicolumn{3}{c}{ Weather Data } \\
\hline & Annual average $\left({ }^{\circ} \mathrm{C}\right)$ & $26.7[38]$ \\
Temperature & Maximum annual average $\left({ }^{\circ} \mathrm{C}\right)$ & $31.6[38]$ \\
& Minimum annual average $\left({ }^{\circ} \mathrm{C}\right)$ & $21.7[38]$ \\
Relative humidity & Annual average $(\%)$ & $79.9[39]$ \\
Precipitation & Mean annual $(\mathrm{mm})$ & $2258.0[38]$ \\
& Annual average $(\mathrm{m} / \mathrm{s})$ & $4.1[39]$ \\
Wind speed & Maximum annual average $(\mathrm{m} / \mathrm{s})$ & $5.9[39]$ \\
& Minimum annual average $(\mathrm{m} / \mathrm{s})$ & $2.4[39]$ \\
\hline
\end{tabular}

Table 2. Building envelope (opaque elements) and U-values.

\begin{tabular}{|c|c|c|c|c|}
\hline Elements & Material & Thickness (mm) & U-Value $\left(\mathrm{W} /\left(\mathrm{m}^{2} \cdot \mathrm{K}\right)\right)$ & Construction Image [41] \\
\hline \multirow{4}{*}{$\begin{array}{l}\text { External wall and } \\
\text { internal partitions }\end{array}$} & & & \multirow{4}{*}{2.99} & Outer surface \\
\hline & Plaster, dense & 10.0 & & \\
\hline & $\begin{array}{c}\text { Concrete block, } \\
\text { hollow, lightweight }\end{array}$ & 62.1 & & \\
\hline & Plaster, dense & 10.0 & & \\
\hline \multirow{3}{*}{$\begin{array}{l}\text { Roof, internal floor, } \\
\text { and external floor. }\end{array}$} & Porcelain floor & 20.0 & \multirow{3}{*}{3.27} & \\
\hline & $\begin{array}{l}\text { Concrete, reinforced } \\
\quad \text { (with } 2 \% \text { steel) }\end{array}$ & 319.0 & & \\
\hline & Plaster, dense & 13.0 & & ce \\
\hline \multirow{3}{*}{ Ground floor } & Porcelain floor & 20.0 & \multirow{3}{*}{1.95} & \\
\hline & Concrete slab & 152.4 & & \\
\hline & Compacted soil & 304.8 & & surface \\
\hline
\end{tabular}

Table 3. Building envelope (fenestration), solar factors and U-value.

\begin{tabular}{ccccc}
\hline Element & Material & U-Value $\left(\mathbf{W} /\left(\mathbf{m}^{2} \cdot \mathbf{K}\right)\right)$ & SHGC & VT \\
\hline \multirow{3}{*}{ Exterior Windows } & Single glazing 6 mm/wood frame & 5.05 & 0.64 & 0.88 \\
& Single glazing 6 mm/aluminum frame & 7.24 & 0.75 & 0.88 \\
& Single glazing 6 mm/no frame & 5.78 & 0.82 & 0.88 \\
\hline
\end{tabular}

Existing publications suggesting thermal properties for concrete materials provide little or no information on the concrete or mortar mixture proportions, limiting the utility for designers desiring to identify inputs for building energy simulation models. However, considering the year of the building construction and specifications of the construction's 
Mexican standards, the concrete mixture proportion of the base case was established as $1: 4: 8$.

\subsection{Software Election}

The energy simulation models were generated and evaluated using DesignBuilder, which is one the most established and advanced building energy simulation tools using the EnergyPlus engine [42]. Designbuilder provides an easy-to-use interface for modelling simulation and quantifying building performance. EnergyPlus is a very powerful simulation engine for studies of building energy including construction, HVAC systems and controls, lighting, thermal mass, and economic analysis. The software is widely used and validated in building energy modelling either for conventional construction materials, or for more complicated building materials such as building integrated phase change materials [43-47].

Since the main purpose of this study was to evaluate the thermal performance simulation of an existing residential building, and due to the possibility of interoperability issues between building information modeling (BIM)-building energy modeling (BEM) appearing during the importation of the BIM information to a building energy analysis software [48-51], which can lead to a rework consisting of re-entering the BIM stored information into the energy model [51], BIM was generated through Designbuilder software.

\subsection{Building Modelling}

For the creation of the model geometry, a total of 3 building blocks were used, which helped to define the different levels of the building. The building's accessories (such as pillars, shading devices, and balconies) and the two adjacent houses, located in the north and south façade of the building (see Figure 1), were established using component blocks. The two adjacent houses were included in the modeling since both houses' height represent important solar obstructions in the project.

The different views of the 3D building model located in Villahermosa are shown in Figure 2 where building blocks are represented in dark gray color, the component blocks in purple, and the location and visual dimensions for the openings (fenestrations and doors) in light gray.

Each building block was internally divided into different thermal zones through the creation of internal partitions. The thermal zones generated at each level are listed below:

- First level: 4 thermal zones were created, consisting of a kitchen, living-dining room, half bathroom, and a study room (see Table 4).

- Second Level: 7 thermal zones were established, which correspond to the master bedroom, master bathroom, bedroom 1, bathroom 1, bedroom 2, bathroom 2, and a corridor (see Table 4).

- Third Level: 2 thermal zones were defined and consist of an office room and utility room (see Table 4).
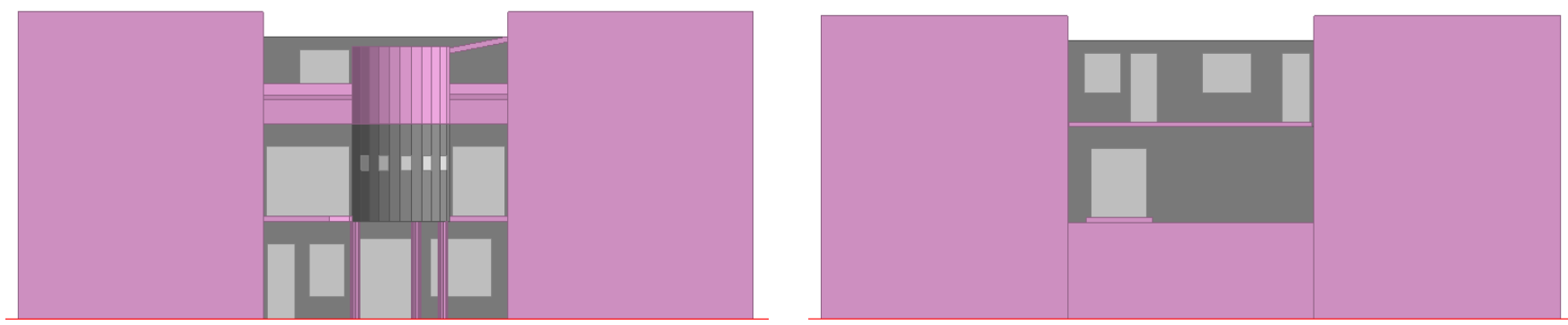

(a)

Figure 2. Cont. 


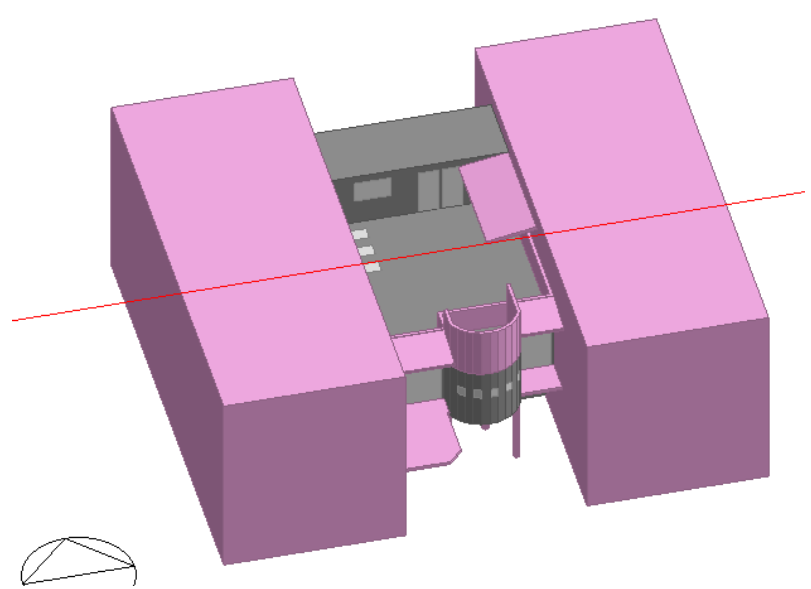

(c)

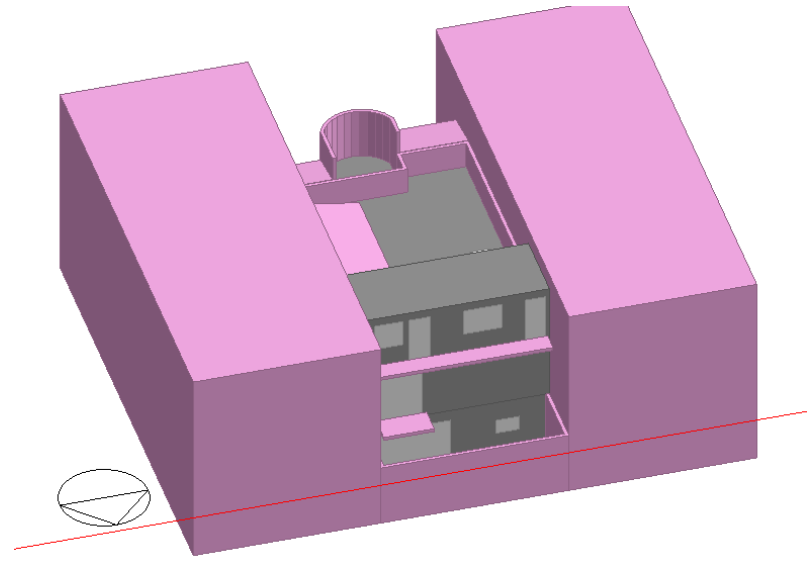

(d)

Figure 2. Visualization of the 3-D building model located in Villahermosa, Tabasco (Mexico): (a) front view; (b) back view; (c) axonometric front view; (d) axonometric back view.

Table 4. Internal partitions defined for the residential building and the surface areas.

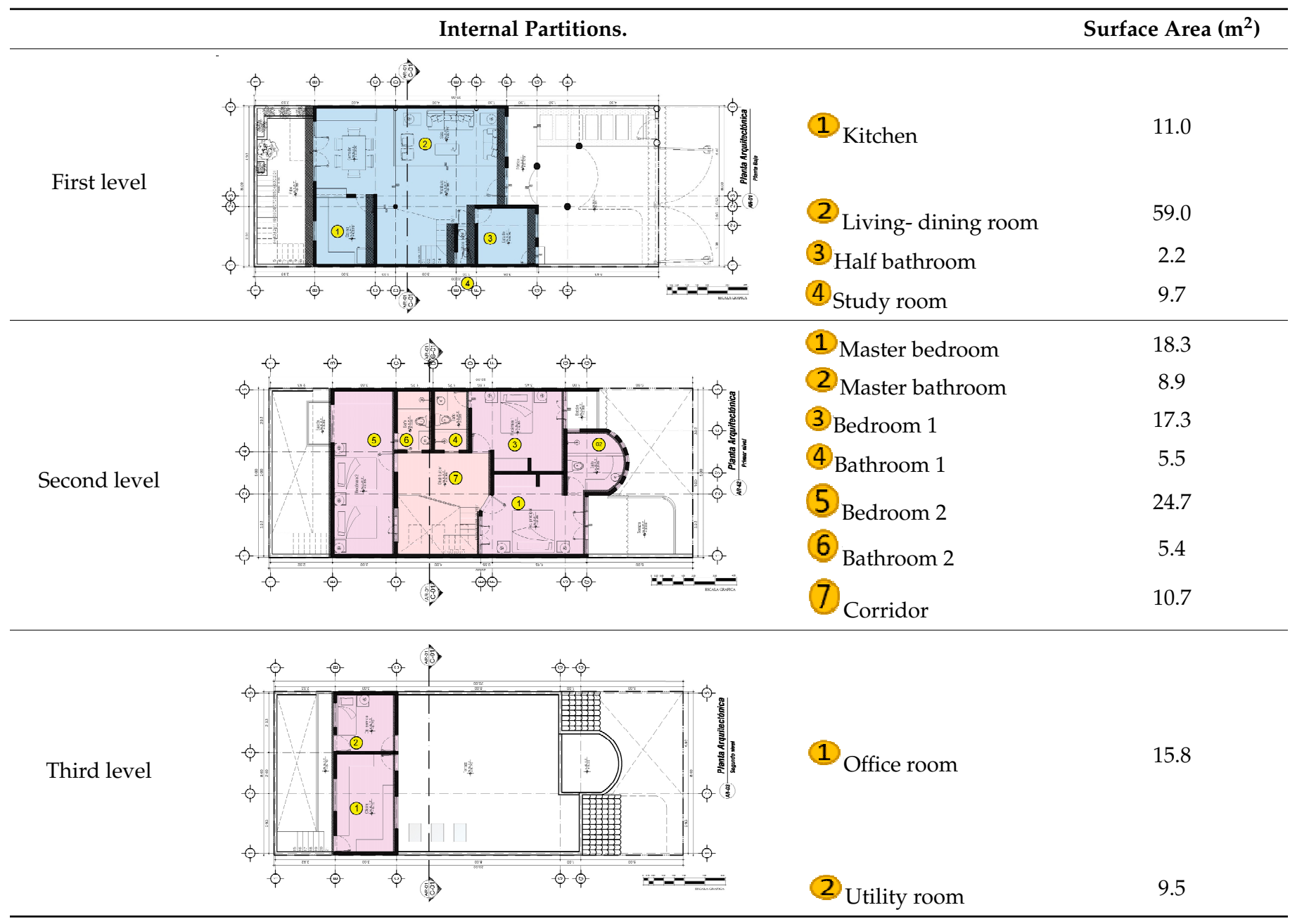

Based on the collected information, the internal gains of the building were defined in DesignBuilder software: occupancy, lighting loads, HVAC controls, plug loads (such as miscellaneous, office equipment, and computer), and operation schedules. The cooling set point temperature was set at $25^{\circ} \mathrm{C}$ and the assigned values for humidification and dehu- 
midification in site were 50\% each, in accordance with the thermal comfort established in ANSI/ ASHRAE standard 55-2017 thermal environmental conditions for human occupancy. The heating set point was set at $0{ }^{\circ} \mathrm{C}$, because on-site heating is not considered necessary, due to the climatic conditions of the location in this study.

The data of occupancy and operational schedules used to simulate in the software are shown in Tables S1-S3 (Supplementary Material).

\subsection{Validation of the Building Model (Base Case)}

To validate the base case model, ASHRAE Guideline 14 was used, which is an established method for measuring a model's accuracy [52-54]. ASHRAE Guideline 14 considered accurate if the mean bias error (MBE) of monthly data is $-5 \% \leq \mathrm{MBE}_{\text {monthly }} \geq 5 \%$ and $\mathrm{CV}(\mathrm{RMSE})_{\text {monthly }} \leq 15 \%$ [47]. The MBE and CV(RMSE) were calculated using Equations (1) and (2).

$$
\begin{aligned}
\mathrm{CV}(\mathrm{RMSE}) & =\frac{\sqrt{\sum_{i=1}^{N_{i}}\left[\left(M_{i}-S_{i}\right)^{2} / N_{i}\right]}}{\frac{1}{N_{i}} \sum_{i=1}^{N_{i}} M_{i}} \\
\mathrm{MBE} & =\frac{\sum_{i=1}^{N_{i}}\left(M_{i}-S_{i}\right)}{\sum_{i=1}^{N_{i}} M_{i}}
\end{aligned}
$$

where CV (RMSE) is the coefficient of variation (CV) of the root mean square error (RMSE); mean bias error (MBE) is an indication of overall bias in a regression model; $M_{i}$ is the actual monthly energy consumption at instance $i ; S_{i}$ is simulated monthly energy consumption at instance $i$; and $N_{i}$ is the number of values involved in the error calculation.

\subsection{Performance Analysis}

The building's performance was evaluated based on the energy performance and economic analysis. Equations (3) and (4) were used to measure the energy savings in the base case building after retrofit.

$$
\begin{gathered}
\text { Energy saving }(\mathrm{kWh})=\text { Energy used (base }- \text { case })- \text { Energy used(retrofit) } \\
\text { Energy saving }(\%)=\frac{\text { Energy saving }(\mathrm{kWh})}{\text { Energy used (base }- \text { case })} \times 100 \%
\end{gathered}
$$

Equation (5) is the discounted payback period (DPP) used as a financial parameter for evaluate the economic feasibility of the final proposal. The DPP is the number of years it takes to break even from undertaking the investment cost $\left(i_{0}\right)$ by discounting the cumulative net present values to base year, which is developed and applied with a specific discounting cash flow approach to evaluate an investment in renovation to improve building quality, thus increasing energy efficiency $[55,56]$.

$$
\mathrm{DPP}=i_{N P V(i)=0}
$$

where DPP is the discounted payback period; $i_{0}$ is the initial investment cost; $N P V$ is the net present value.

The Equation (6) measures the net present value (NPV), which is the sum of the incoming and outgoing cash flows $(C F)$, over a defined time horizon $(T)$, discounted at the discount rate $(r)$, less the initial investment $\left(i_{0}\right)[56]$.

$$
\mathrm{NPV}=\sum_{i=0}^{T} \frac{C F}{(1+r)^{i}}-i_{0} \geq 0
$$




\section{Results and Discussion}

\subsection{Base Case Simulation}

The thermal energy performance simulation was made to analyze the internal and external heat gains/losses of the building. The actual and simulated monthly electricity consumption of the residential building studied (base case) is shown in Table 5. The results showed that the MBE electricity consumption is $-4.1 \%$ and the CV (RMSE) is $14.1 \%$. Thus, the values are within the acceptable limits to be considered as accurate according to the ASHRAE Guideline 14.

Table 5. The actual and simulated electricity consumption.

\begin{tabular}{ccc}
\hline Month & Actual (kWh) & Simulated (kWh) \\
\hline January & 442 & 472.54 \\
February & 1670 & 1661 \\
March & & \\
April & 3142 & 3231 \\
May & 3274 & 3427 \\
June & 3058 & 3143 \\
July & 1784 & 1845 \\
August & 483 & 480 \\
September & & \\
October & & \\
November & &
\end{tabular}

The monthly heat gains result by the base case throughout the year can be seen in Figure 3, caused by walls, ceilings, floors, ground floors, partitions, roof, lighting, miscellaneous, catering, computers and equipment, occupancy, solar gains, and zonesensible cooling. In this figure, we can see that the greater heat gain is due to the increase in solar gains by exterior windows, followed by the roof, occupancy, and lastly, by the walls. On the other hand, it can be observed that the primary heat loss of the building is due to the interior floors and through the ground floor, which is responsible for reducing the sensible cooling zone of the building.

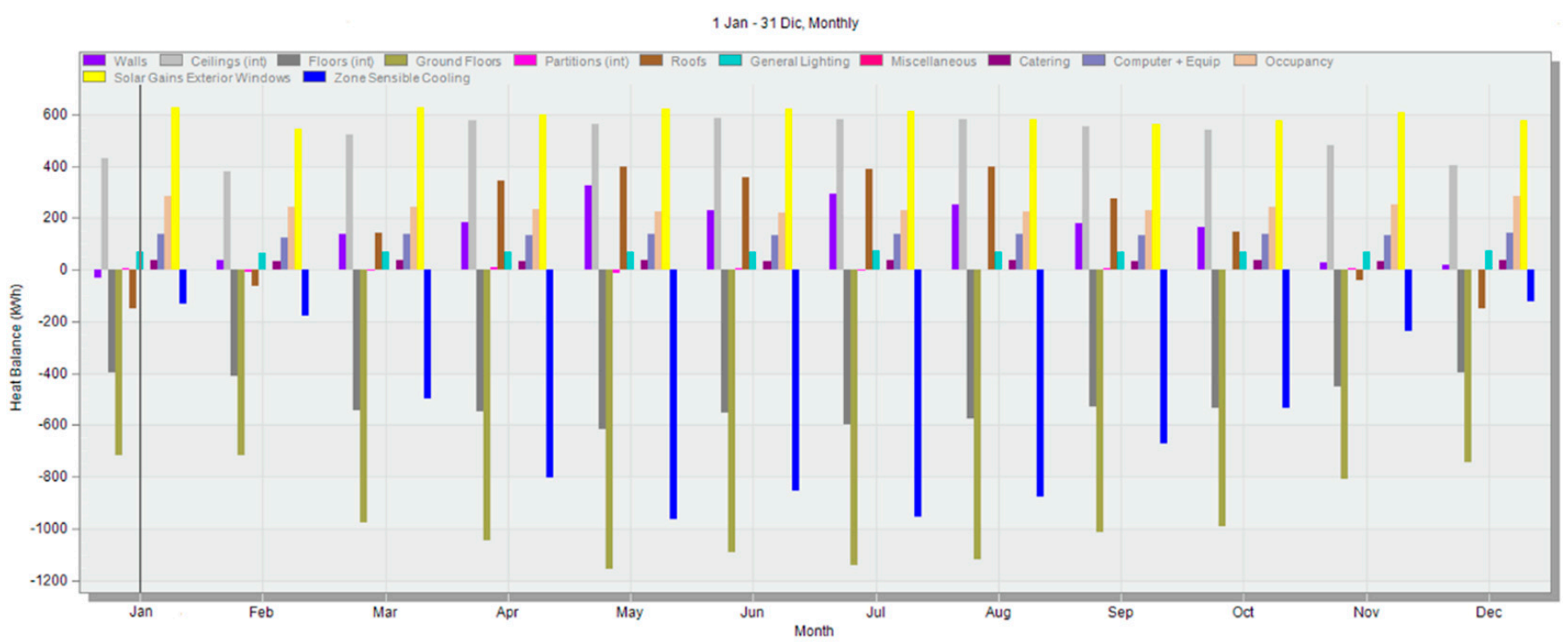

Figure 3. Monthly heat gains/losses of the base case. 


\subsection{Passive Design Strategies Proposed}

Once the results of the thermal energy performance simulation of the base case were analyzed, different passive design strategies were proposed, which were based on those enclosures and/or openings that had greater contributions of heat gains in the base case: exterior windows, roofs, and walls. Regarding the occupancy, which represents the third position of the heat gains in the base case, it is not feasible to be modified, since it would signify changes in the occupancy hours, the number of occupants, or the current metabolic conditions.

The passive design strategies proposed for the residential building are described hereafter:

- Exterior windows: To reduce the solar gains, which represent the greatest heat gain, it was proposed to add another glass with a thickness of $13 \mathrm{~mm}$ in all the windows placing air in between them (see Figure 4). In the same way, since the frames influence the thermal behavior of the window, it was proposed to change the aluminum frames to wooden frames and place wooden frames on exterior windows with "no frames", to improve their thermal properties. Table 6 describes the thermal properties of the exterior windows, both base case and with the proposed passive design strategy.

- Roof: To reduce the heat gains in this enclosure and maintain the interior thermal comfort, a passive design strategy was proposed on roofs through the installation of expanded polystyrene (EPS) insulation panels. A total of 4 different thicknesses of the insulation material was proposed, to achieve compliance with the U-values established in two different Mexican standards: the official Mexican standard NOM020-ENER-2011 [26], whose adoption is mandatory, and the Mexican standard NMXC-460-ONNCCE-2009 [27], which is voluntary. Both standards focus on limiting the heat gains through the building envelope. Regarding the NMX-C-460, the Mexican standard suggests specifications for R-values in three categories: "minimum", "habitability", and "energy-saving" [27]. The construction layers and the thermal properties of the roofs in the base case building and the building with the proposed passive design strategy are shown in Table 8 , in which scenario 1 corresponds to the base case building (without thermal insulation), scenario 2 represents the three categories of the NMX-C-460, and scenario 3 corresponds to the compliance with the NOM-020.

- Walls: As in roofs, the installation of expanded polystyrene (EPS) insulation panels inside the building was proposed as a passive design strategy to reduce the thermal load (heat-cold) on the walls. A total of 4 different thicknesses of the insulation were proposed to achieve compliance with the U-values of two different Mexican standards: The official Mexican standard NOM-020 [26], and the voluntary Mexican standard NMX-C-460 [27]. Table 7 describes the construction layers and thermal properties on walls of the different simulated scenarios: the scenario 1 corresponds to the base case building, which has no thermal insulation on walls, scenario 2 describes the three categories of the NMX-C-460, and scenario 3 corresponds to the compliance with the NOM-020.

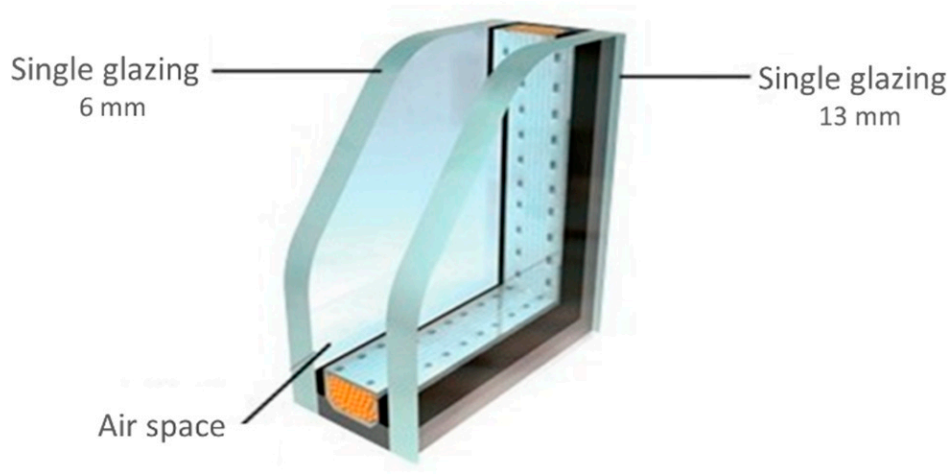

Figure 4. Passive design strategy proposed for the external window. 
Table 6. Thermal properties of the exterior windows in the base case building and the building with the proposed passive design strategy.

\begin{tabular}{|c|c|c|c|c|c|c|}
\hline \multirow{2}{*}{ Fenestration Type } & \multicolumn{3}{|c|}{$\begin{array}{l}\text { Base Case Building: } \\
\text { Single Glazing } 6 \mathrm{~mm}\end{array}$} & \multicolumn{3}{|c|}{$\begin{array}{l}\text { Passive Design Strategy on Exterior Windows: Double } \\
\text { Glazing } 6 \mathrm{~mm} / 13 \mathrm{~mm} \text { Filled with Air/Wood Frame }\end{array}$} \\
\hline & U-Value $\left(\mathrm{W} /\left(\mathrm{m}^{2} \cdot \mathrm{K}\right)\right)$ & SHGC & VT & U-Value $\left(\mathrm{W} /\left(\mathrm{m}^{2} \cdot \mathrm{K}\right)\right)$ & SHGC & VT \\
\hline Wood frame. & 5.05 & 0.64 & 0.88 & & & \\
\hline Aluminum frame. & 7.24 & 0.75 & 0.88 & 2.87 & 0.57 & 0.781 \\
\hline No frame. & 5.78 & 0.82 & 0.88 & & & \\
\hline
\end{tabular}

Table 7. Construction layers and thermal properties of the walls in the base case building and the building with the proposed passive design strategy.

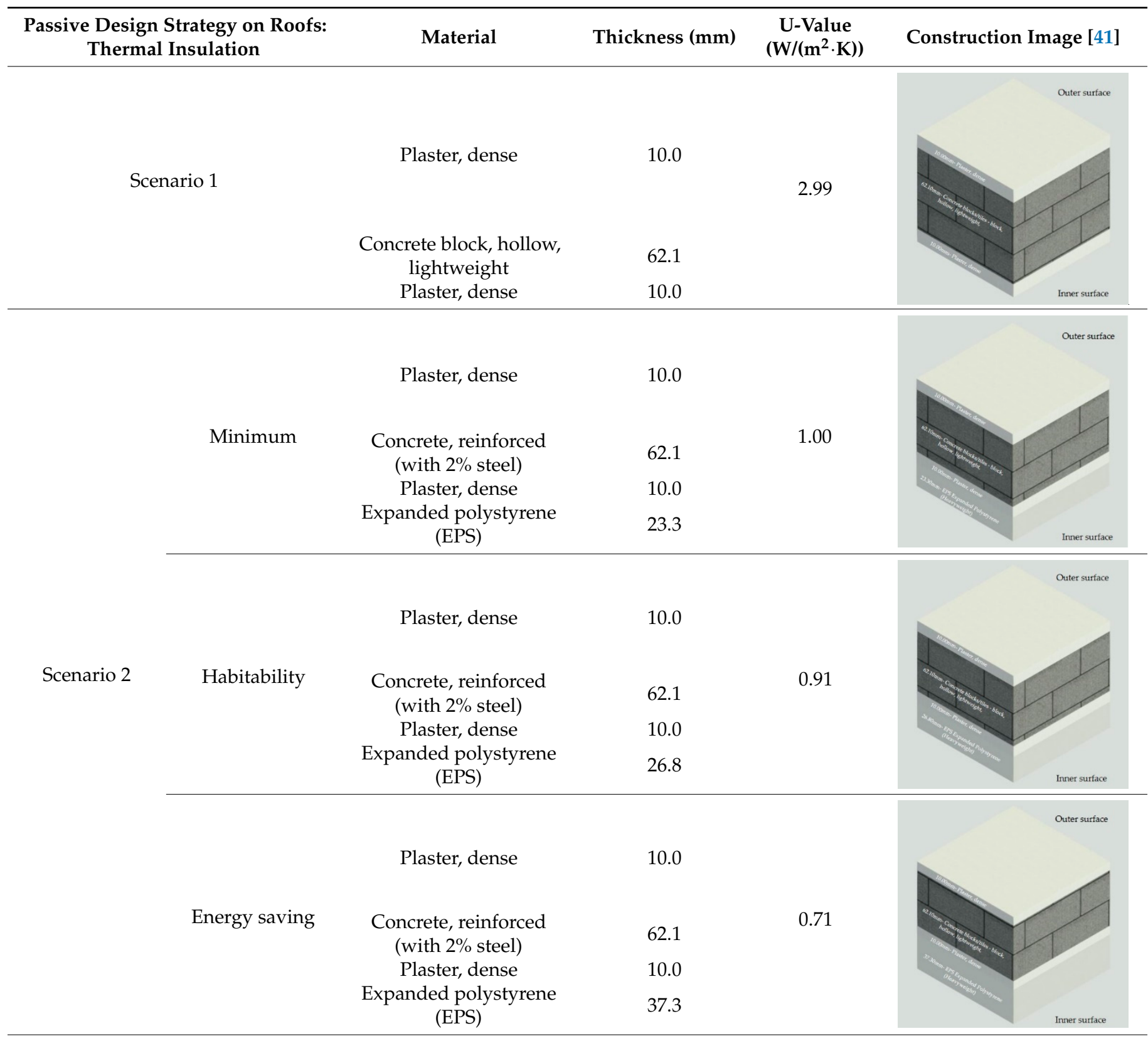


Table 7. Cont.

\begin{tabular}{|c|c|c|c|c|}
\hline $\begin{array}{c}\text { Passive Design Strategy on Roofs: } \\
\text { Thermal Insulation }\end{array}$ & Material & Thickness (mm) & $\begin{array}{l}\text { U-Value } \\
\left(\mathrm{W} /\left(\mathrm{m}^{2} \cdot \mathrm{K}\right)\right)\end{array}$ & Construction Image [41] \\
\hline \multirow{5}{*}{ Scenario 3} & & & \multirow{5}{*}{0.53} & Outer surface \\
\hline & Plaster, dense & 10.0 & & \\
\hline & $\begin{array}{l}\text { Concrete, reinforced } \\
\text { (with } 2 \% \text { steel) }\end{array}$ & 62.1 & & \\
\hline & Plaster, dense & 10.0 & & \\
\hline & $\begin{array}{l}\text { Expanded polystyrene } \\
\text { (EPS) }\end{array}$ & 54.8 & & Irneer surface \\
\hline
\end{tabular}

Table 8. Construction layers and thermal properties of the roofs in the base case building and the building with the proposed passive design strategy.

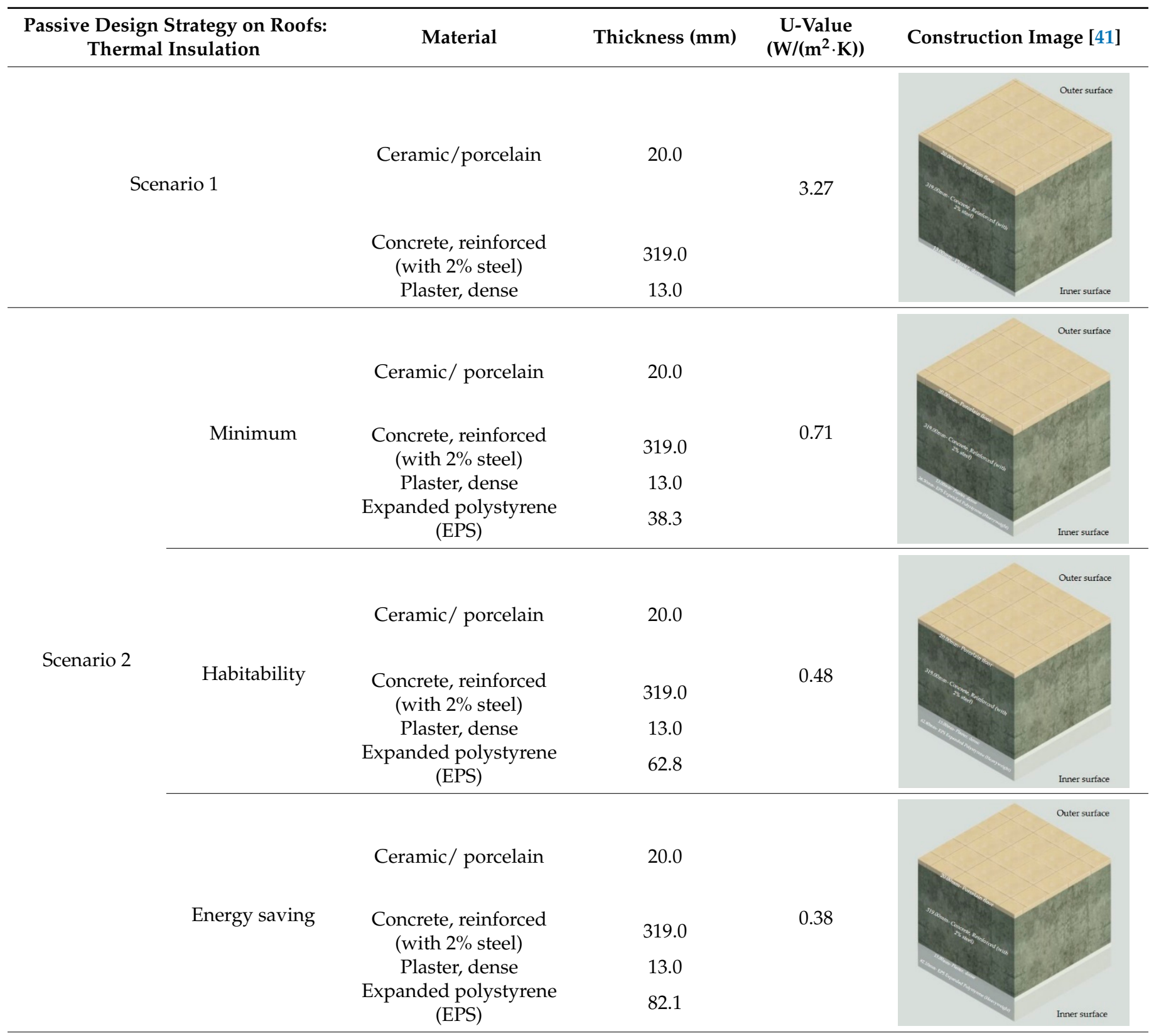


Table 8. Cont.

\begin{tabular}{|c|c|c|c|c|}
\hline $\begin{array}{c}\text { Passive Design Strategy on Roofs: } \\
\text { Thermal Insulation }\end{array}$ & Material & Thickness (mm) & $\begin{array}{c}\text { U-Value } \\
\left(\mathrm{W} /\left(\mathrm{m}^{2} \cdot \mathrm{K}\right)\right)\end{array}$ & Construction Image [41] \\
\hline \multirow{4}{*}{ Scenario 3} & Ceramic/ porcelain & 20.0 & \multirow{4}{*}{0.53} & \\
\hline & $\begin{array}{l}\text { Concrete, reinforced } \\
\text { (with } 2 \% \text { steel) }\end{array}$ & 319.0 & & \\
\hline & Plaster, dense & 13.0 & & \\
\hline & $\begin{array}{l}\text { Expanded polystyrene } \\
\text { (EPS) }\end{array}$ & 55.8 & & Inner surface \\
\hline
\end{tabular}

\subsection{Simulation of the Different Passive Design Strategies}

For the present model, the thermal energy performance simulation of the building with the different passive design strategies described in the previous section was carried out. The aim was to evaluate the thermal energy performance and observe the impact that each passive design strategy represents in the reduction of the heat gains. The results obtained for each of the passive design strategies are described below:

- Exterior windows: The output energy performance of the building by replacing the fenestration type was analyzed and compared with the base case. A reduction in energy consumption of $2 \%$ was observed, going from energy consumption of $14,416.76 \mathrm{kWh}$ to $14,129.09 \mathrm{kWh}$, described in Table 9.

Table 9. Energy performance of the base case vs the building with the proposed passive design strategy on exterior windows.

\begin{tabular}{|c|c|c|}
\hline & \multirow{2}{*}{ Base Case } & Passive Design Strategy on Exterior Windows: \\
\hline & & Double Glazing $6 \mathrm{~mm} / 13 \mathrm{~mm}$ Filled with Air/Wood Frame \\
\hline Annual electricity consumption (kWh) & $14,416.76$ & $14,129.09$ \\
\hline Energy saving $(\mathrm{kWh})$ & 0.00 & 287.67 \\
\hline Energy saving (\%) & $0.0 \%$ & $2.0 \%$ \\
\hline
\end{tabular}

The results of the heat balance with the implementation of the proposed passive design strategy in exterior windows are shown in Figure 5. The solar gains from exterior windows decreased in comparison with the base case (Figure 3) and, therefore, the sensible cooling of the zone. In general, the average reduction percentage obtained from solar gains in exterior windows was $22.81 \%$, with March, May, and June being the months with the highest external heat gains with $487 \mathrm{kWh}$ and, on the contrary, the month with the lowest heat gains was February with $420 \mathrm{kWh}$. Regarding the sensible cooling zone, it was reduced by $1.96 \%$ compared to the base case.

- $\quad$ Roofs: Table 10 shows the energy performance results and Figure 6 shows the heat gains / losses as a result of the thermal energy performance simulation of each passive design strategy on roofs. As expected, the lower energy consumption compared to the base case (see Figure 6), corresponded to the building that complies with the NMX-C-460-ONNCCE-2009 [27] in the range of "energy saving" (Figure 6c) since it is the one with the best thermal properties. On the other hand, the lowest savings in energy consumption presented was the one that complies with the same standard, but for the "minimum" range (Figure 6a).

- Walls: Regarding the energy performance of the building with passive design strategy on walls, as shown in Table 11 and Figure $7 d$, the proposal that had the greatest energy savings compared to the base case corresponded to the building that complies with the NOM-020 [26] standard, since it is the one with the best thermal properties. On 
the other hand, the one with the minimum energy savings was the one that complies with the NMX-C-460 [27] standard for the "minimum" range (Figure 7a).

Table 10. Energy performance of the base case vs the building with the proposed passive design strategy on roofs.

\begin{tabular}{|c|c|c|c|c|c|}
\hline & \multirow{3}{*}{ Base Case } & \multicolumn{4}{|c|}{ Passive Design Strategy on Roofs: Thermal Insulation with EPS } \\
\hline & & \multicolumn{3}{|c|}{ NMX-C-460-ONNCCE-2009 } & \multirow{2}{*}{ NOM-020-ENER-2011 } \\
\hline & & Minimum & Habitability & Energy Saving & \\
\hline $\begin{array}{c}\text { Annual electricity } \\
\text { consumption (kWh) }\end{array}$ & $14,416.76$ & $12,678.89$ & $12,500.15$ & $12,441.99$ & $12,529.88$ \\
\hline Energy saving (kWh) & 0.00 & 1737.87 & 1916.61 & 1974.77 & 1886.88 \\
\hline Energy saving $(\%)$ & $0.0 \%$ & $12.1 \%$ & $13.3 \%$ & $13.7 \%$ & $13.1 \%$ \\
\hline
\end{tabular}

Table 11. Energy performance of the base case vs the building with the proposed passive design strategy on walls.

\begin{tabular}{|c|c|c|c|c|c|}
\hline & \multirow{3}{*}{ Base Case } & \multicolumn{4}{|c|}{ Passive Design Strategy on Walls: Thermal Insulation with EPS } \\
\hline & & \multicolumn{3}{|c|}{ NMX-C-460-ONNCCE-2009 } & \multirow{2}{*}{ NOM-020-ENER-2011 } \\
\hline & & Minimum & Habitability & Energy Saving & \\
\hline $\begin{array}{l}\text { Annual electricity } \\
\text { consumption (kWh) }\end{array}$ & $14,416.76$ & $13,874.93$ & $13,845.72$ & $13,782.57$ & $13,714.65$ \\
\hline Energy saving (kWh) & 0.00 & 541.83 & 571.04 & 634.19 & 702.11 \\
\hline Energy saving (\%) & $0.0 \%$ & $3.8 \%$ & $4.0 \%$ & $4.4 \%$ & $4.9 \%$ \\
\hline
\end{tabular}

\subsection{Final Proposal for Adaptation of Passive Design Strategies}

Once the energy performance of the building was analyzed with the simulation of the different adaptation proposals with passive design strategies in exterior windows, roofs, and walls, a final adaptation proposal was established, selecting those passive design strategies whose results represented the highest energy savings in the building, in order to evaluate its final energy performance and to ascertain the total energy savings that the implementation of these strategies presents in comparison with the base case. Table 12 shows the passive design strategies chosen and the results in total energy savings.

As shown in Figure 8, the heat gains and losses of the building with the final adaptation proposal described in Table 12 decreased significantly in comparison to the base case (Figure 3). Regarding heat gains, specifically, we can see that the walls were the enclosure with the highest average reduction percentage, with $79.38 \%$, going from $157.30 \mathrm{kWh}$ to $32.43 \mathrm{kWh}$; followed by the roofs with $40.85 \%$ (from $520.11 \mathrm{kWh}$ to $307.66 \mathrm{kWh}$ ); and, thirdly, exterior windows with a $23.55 \%$ reduction (from $601.58 \mathrm{kWh}$ to $459.91 \mathrm{kWh}$ ), since the proposed strategies are mainly focused on reducing the heat gains of these enclosures and openings. Regarding the heat losses of the building, we see that a reduction was also obtained and the sensible cooling of the area presented a decrease of $33.28 \%$ (from $-561.72 \mathrm{kWh}$ to $-374.77 \mathrm{kWh}$ ).

On the other hand, we can corroborate that the behavior of sensible cooling zone is related to the average temperatures of the state of Tabasco, since the higher the outside temperature, the greater the sensible cooling required by the building. The months of May and July are the months with the highest sensible cooling in the area, with $-583.78 \mathrm{kWh}$. Moreover, the percentage of energy savings in consumption from the base case shows that the more sensible cooling zone is required in the building, the higher the percentage of energy saving is achieved. However, January and December showed an increase in energy consumption needed to achieve thermal comfort (see Figure 9). 


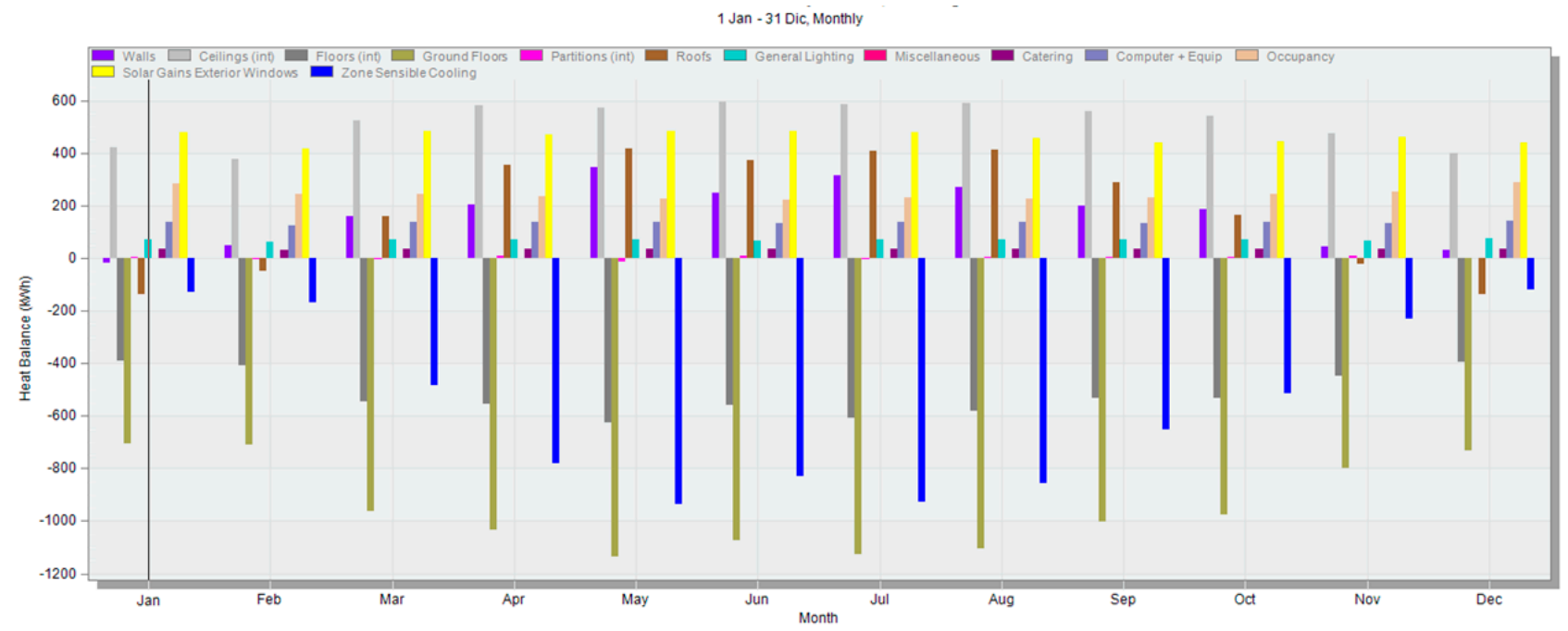

Figure 5. Heat gains/losses in the building with the proposed passive design strategy in exterior windows.

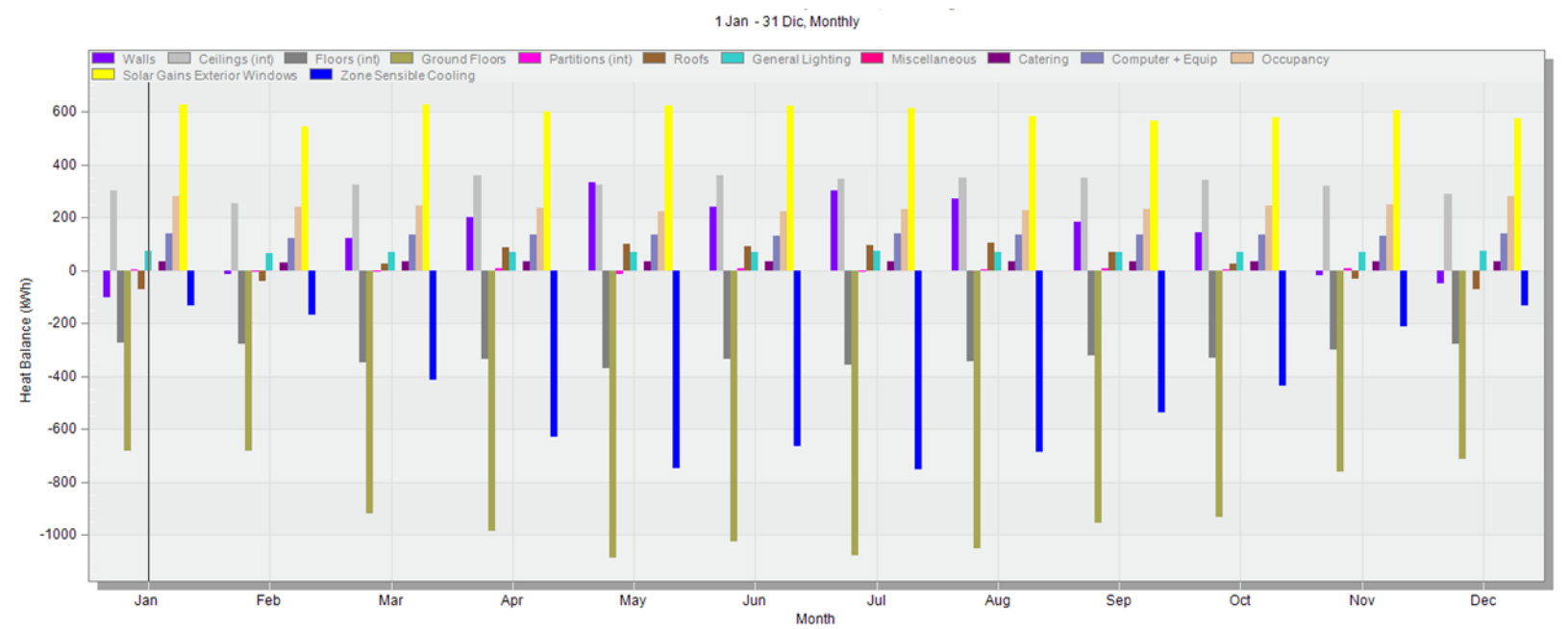

(a)

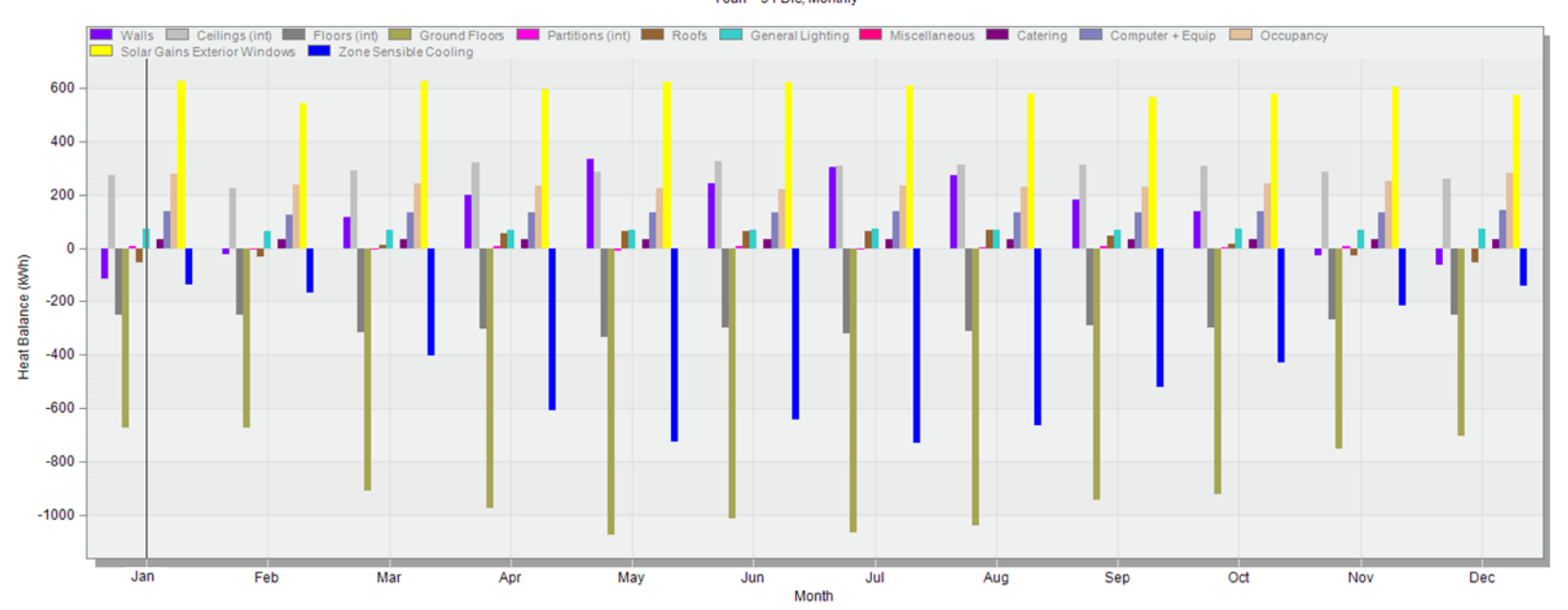

(b)

Figure 6. Cont. 


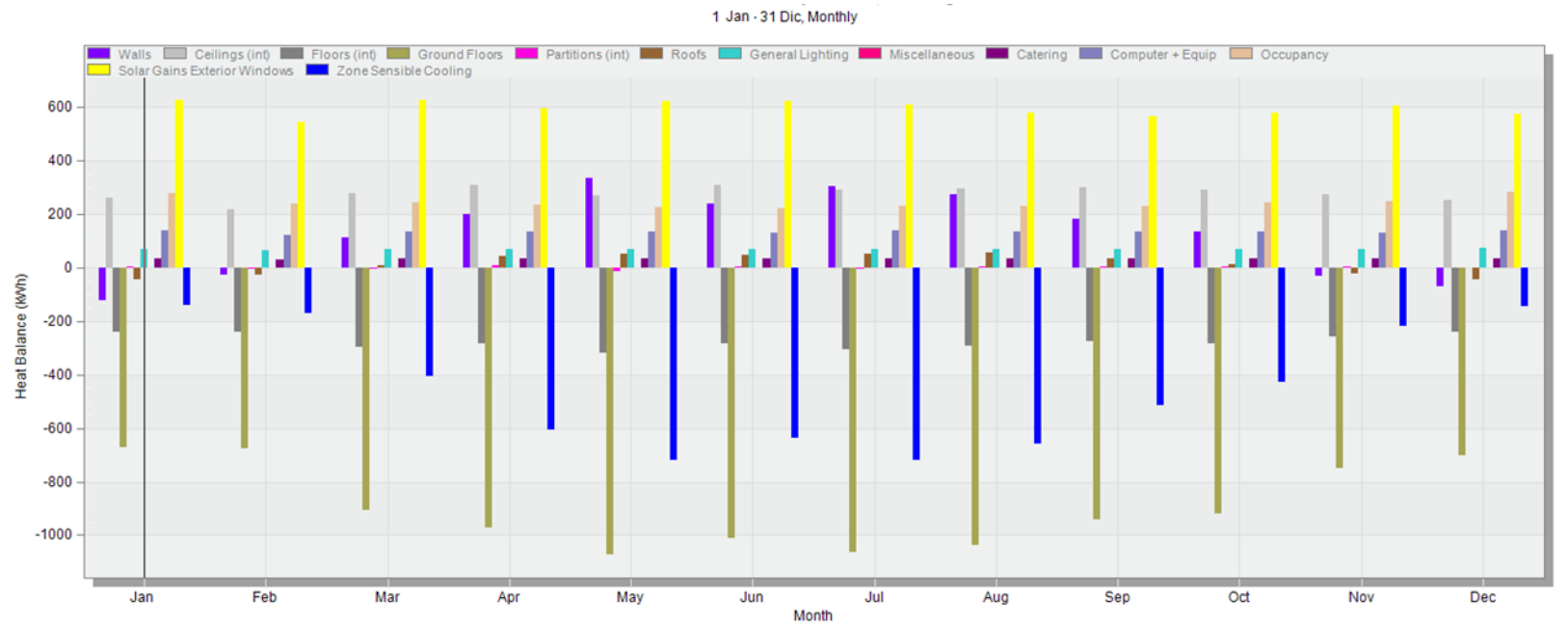

(c)

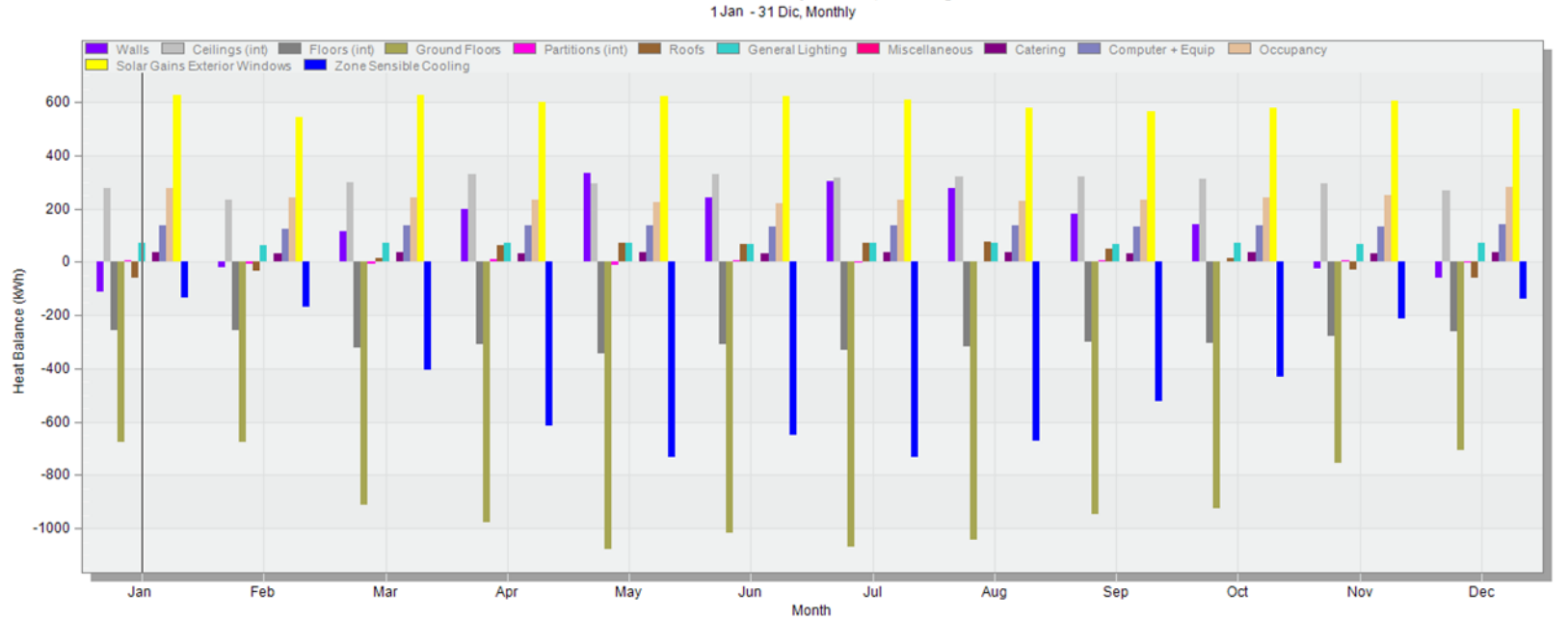

(d)

Figure 6. Heat gains/losses in the building with the proposed passive design strategy on roofs in compliance with: (a) NMX-C-460-ONNCCE-2009 “Minimum" range; (b) NMX-C-460-ONNCCE-2009 "Habitability" range; (c) NMX-C-460ONNCCE-2009 “Energy saving” range; (d) NOM-020-ENER-2011.

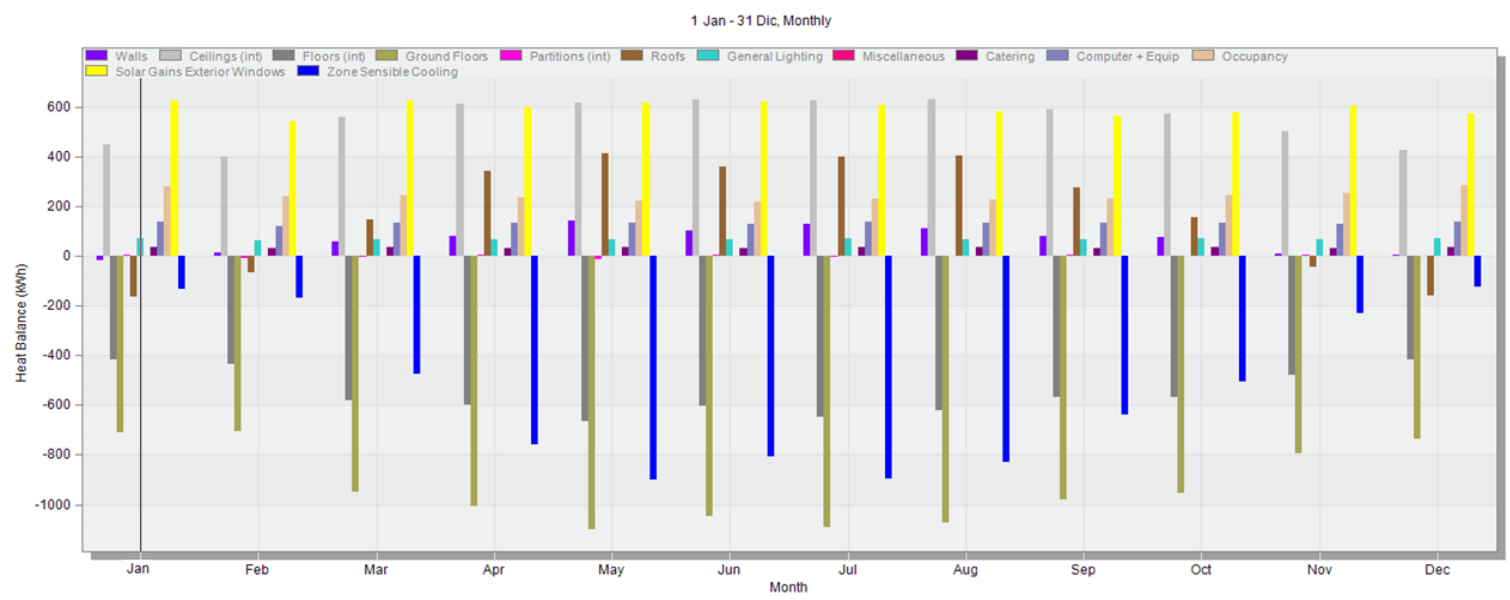

(a)

Figure 7. Cont. 


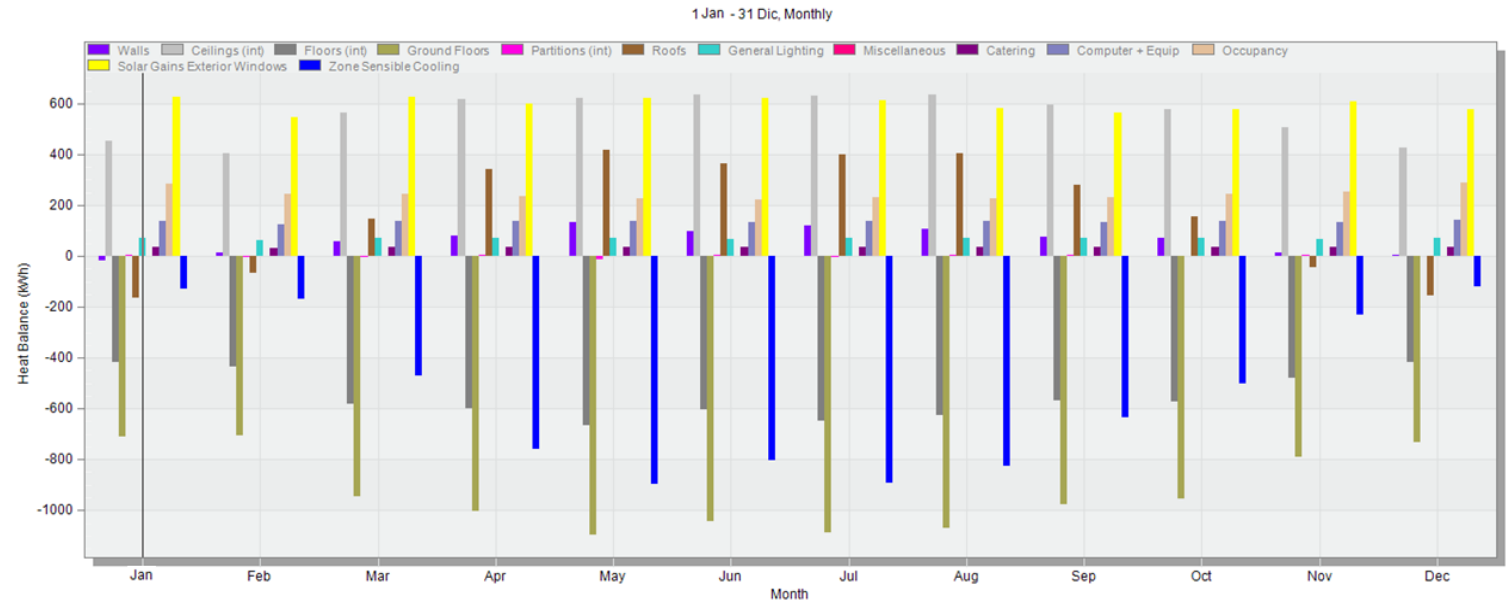

(b)

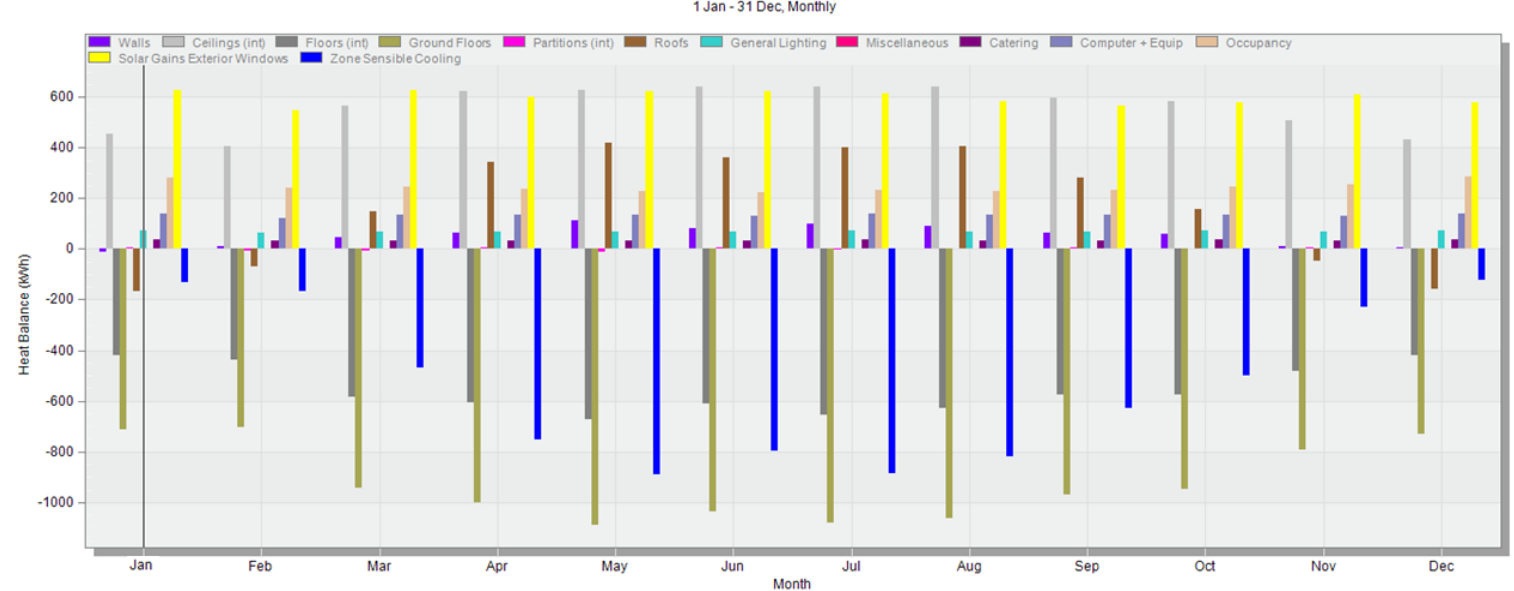

(c)

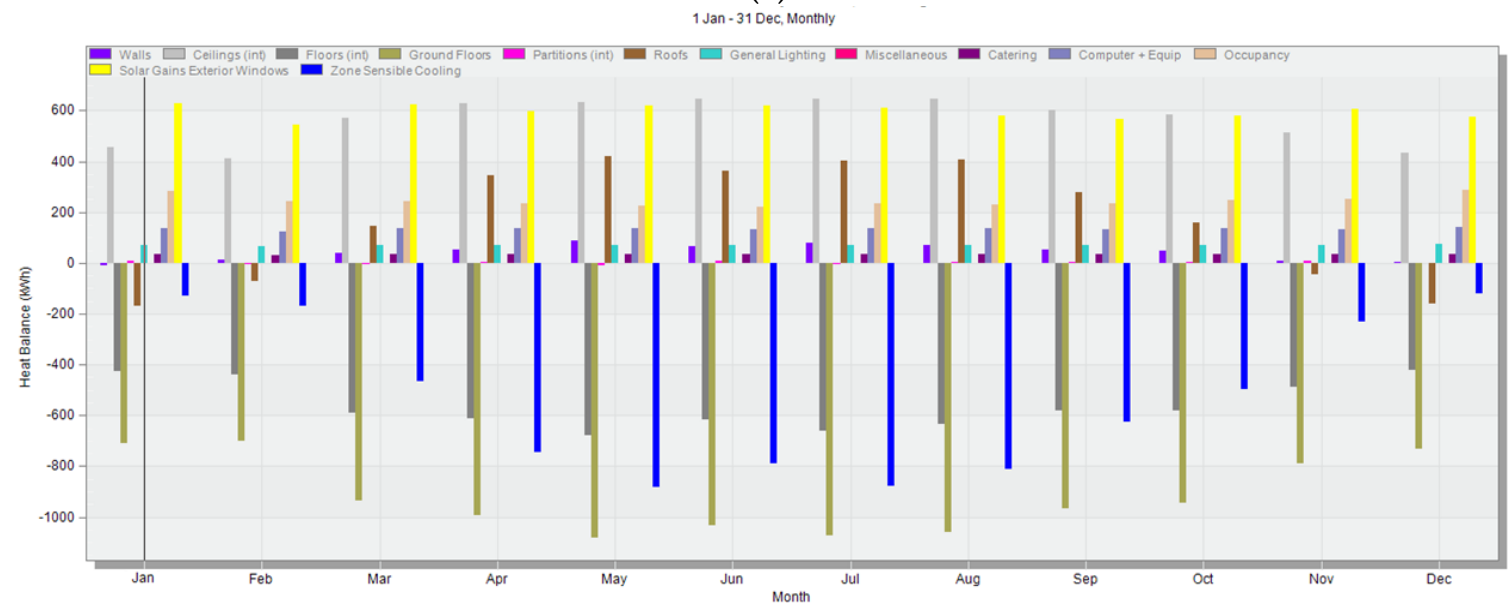

(d)

Figure 7. Heat gains/losses in the building with the proposed passive design strategy on walls in compliance with: (a) NMX-C-460-ONNCCE-2009 “Minimum” range; (b) NMX-C-460-ONNCCE-2009 “Habitability” range; (c) NMX-C-460ONNCCE-2009 “Energy saving” range; (d) NOM-020-ENER-2011. 


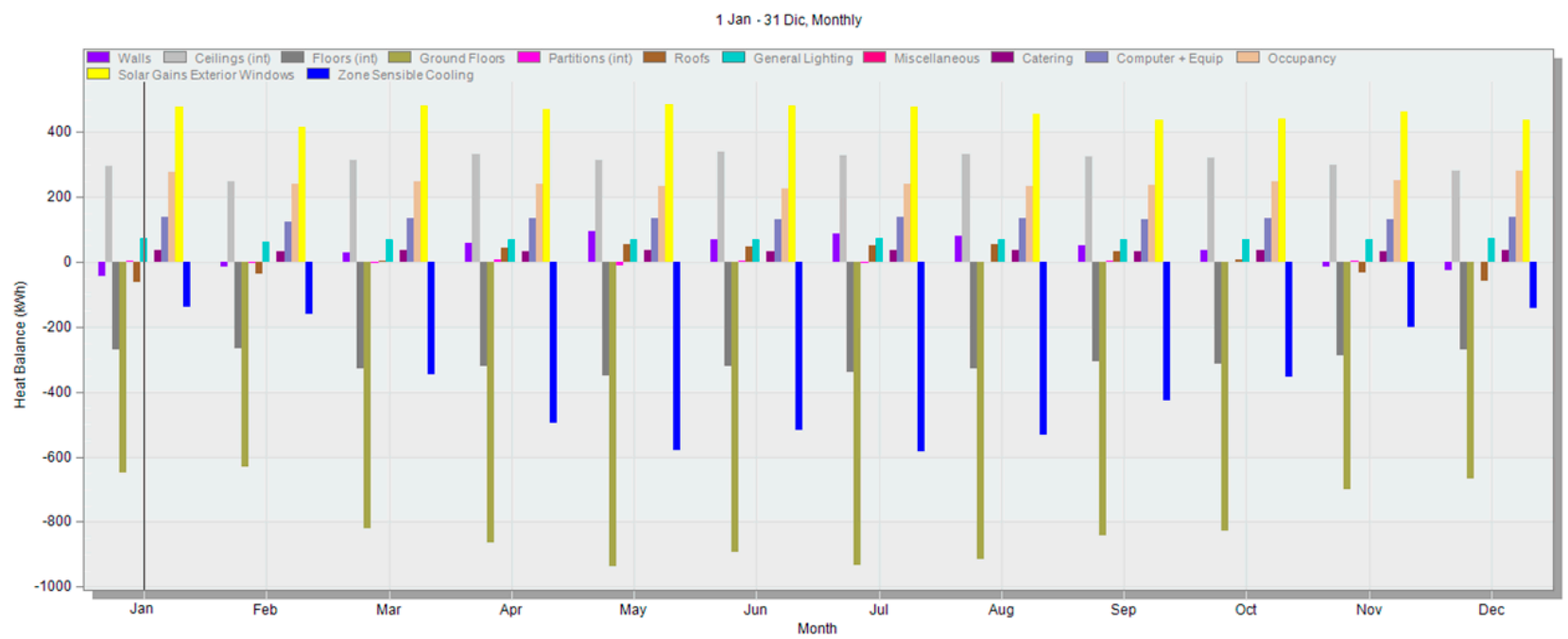

Figure 8. Heat gains/losses in the building with the final adaptation proposal of passive design strategy.

Table 12. Energy performance of the base case vs the building with the final proposal with passive design strategies.

\begin{tabular}{|c|c|c|}
\hline & Base Case & $\begin{array}{l}\text { Final Proposal with Passive } \\
\text { Design Strategies: }\end{array}$ \\
\hline & $\begin{array}{l}\text { Exterior windows: Single glazing } \\
6 \mathrm{~mm} / \text { wood, aluminum, } \\
\text { and no frame. } \\
\text { Roofs: Without thermal insulation. } \\
\text { Walls: Without thermal insulation. }\end{array}$ & $\begin{array}{l}\text { Exterior windows: Double glazing } \\
6 \mathrm{~mm} / 13 \mathrm{~mm} \text { filled with air/wood frame. } \\
\text { Roofs: With thermal insulation complying } \\
\text { with the NMX-C-460-ONNCCE-2009 } \\
\text { (Energy saving). } \\
\text { Walls: With thermal insulation complying } \\
\text { with the NOM-020-ENER-2011. }\end{array}$ \\
\hline Annual electricity consumption (kWh) & $14,416.76$ & $11,030.44$ \\
\hline Energy saving $(\mathrm{kWh})$ & 0.00 & $3,386.32$ \\
\hline Energy saving (\%) & $0.0 \%$ & $23.5 \%$ \\
\hline
\end{tabular}

\begin{tabular}{||l|c|c|c|c|c|c|c|c|c|c|c|c|}
\cline { 2 - 12 } \multicolumn{1}{l|}{} & January & February & March & April & May & June & July & August & September & October & November & December \\
\hline $\begin{array}{l}\text { Mean Temperature } \\
\left({ }^{\circ} \mathrm{C}\right)\end{array}$ & 22.8 & 24.6 & 26.1 & 28.2 & 29.3 & 28.4 & 28.4 & 28.4 & 27.9 & 25.1 & 25.1 & 24.0 \\
\hline $\begin{array}{l}\text { Sensible cooling zone } \\
\text { (kWh) }\end{array}$ & -140.5 & -162.2 & -345.9 & -497.3 & -583.8 & -518.9 & -583.8 & -535.1 & -427.0 & -356.8 & -200.0 & -145.9 \\
\hline Energy saving (\%) & -3.87 & 6.84 & 21.74 & 28.25 & 29.71 & 28.71 & 29.18 & 29.41 & 27.42 & 23.38 & 8.75 & -6.88 \\
\hline
\end{tabular}

Figure 9. Mean temperature $\left({ }^{\circ} \mathrm{C}\right)$ of Tabasco vs sensible cooling zone $(\mathrm{kWh})$ and monthly energy savings of the building with the final proposed of passive design strategy.

\subsection{Economic Analysis}

The annual economic savings that could be achieved if the proposed strategies were implemented were calculated through a discounted payback period. To carry out the above, the estimated initial investment cost was calculated through the average market prices of Villahermosa, Tabasco as shown in Table 13. As a result, the initial investment cost of the passive design strategy proposed is $\$ 39,364.30 \mathrm{MXN}$ in total.

As shown in Table 12, the total energy saving of the retrofitted building with the final proposal for adaptation of passive design strategies is $3386.32 \mathrm{kWh}$, which represents a total energy saving of $23.50 \%$. The electricity price in this region according to the building electricity bills is $\$ 2.28 / \mathrm{kWh}$, therefore, the cost of saved electricity is $\$ 7720.82$ per year. 
The discounted payback period was calculated using Equation (5), resulting in 5.8 years based on a discount rate of $4.02 \%$ [57]. Moreover, in accordance with the guide to estimated useful life and depreciation percentages [58], the useful life of a residential building is approximately 50 years. The residential building studied (base case) has been occupied for 18 years since 2003 and considering that the retrofitting project will last for a month, the owner could start to turn a profit in 2027 and continue to benefit for the remaining 26 years.

Table 13. Estimation of the initial investment cost.

\begin{tabular}{lccc}
\hline \multicolumn{1}{c}{ Passive Design Strategy } & Unit Cost & Project Volume & Total Cost \\
\hline Exterior windows: Double glazing 6 mm/13 mm filled with air/wood frame. & $\$ 345.11 / \mathrm{m}^{2}$ & $41.61 \mathrm{~m}^{2}$ & $\$ 14,359.86$ \\
\hline $\begin{array}{l}\text { Roofs: With thermal insulation complying with the } \\
\text { NMX-C-460-ONNCCE-2009 (Energy saving). }\end{array}$ & $\$ 64.09 / \mathrm{m}^{2}$ & $101.01 \mathrm{~m}^{2}$ & $\$ 6474.00$ \\
\hline $\begin{array}{l}\text { Walls: Thermal insulation with expanded polystyrene (EPS) complying } \\
\text { the NOM-020-ENER-2011. }\end{array}$ & $\$ 63.78 / \mathrm{m}^{2}$ & $254.65 \mathrm{~m}^{2}$ & $\$ 16,242.00$ \\
\hline Brick layer specialist & $\$ 163.46 /$ day & 2 persons & $\$ 2288.44 /$ week \\
\hline
\end{tabular}

\section{Conclusions}

Through building energy modeling (BEM), it is feasible to evaluate the energy performance of the building studied, which will depend on both external and internal heat gains of the building; the modeling can also be used as a base tool to determine the impact that passive design strategies will entail for improve the energy-efficiency of the building. The simulation results show that the envelope of a building has an enormous impact on the amount of energy necessary to maintain the interior temperature within a comfortable range: a consequence of the hot-humid climate region of the location. Thus, by improving the thermal properties of these enclosures, we can reduce the amount of heat that enters the building, therefore reducing the amount of energy needed for cooling. Moreover, the annual electricity consumption of the residential building (base case) decreased when simulating each of the strategies proposed for the enclosures, reaching a maximum reduction of $2.0 \%$ in exterior windows, up to $4.9 \%$ in walls and a $13.7 \%$ reduction in roofs, the latter being the enclosure with the greatest reduction achieved. On the other hand, the results of the final adaptation proposal showed the greatest energy savings by improving the energy efficiency of the building, reducing electricity consumption by up to $23.5 \%$ compared to the base case. Moreover, the economic analysis showed that the payback period for the final proposal with the passive design strategies was 5.8 years, therefore the owner can be benefited in the remaining lifetime of the building.

The results of this study are of particular interest given since the structural elements of the thermal envelope and interior partitions of the simulated base case building are typical for the residential buildings in Mexico. Therefore, this study can be replicable not only in Villahermosa, Tabasco but in those federal entities whose climatic regions are similar to the one studied. On the other hand, it is imperative to highlight the importance of the implementation of current efficiency policies in Mexico for both new and existing residential buildings, since the results shown a great reduction in the annual electricity consumption through the improvement of the thermal envelope.

Although there are several passive design strategies, this study evaluated the reduction of energy consumption through the implementation of passive design strategies in the walls, roofs, and exterior windows, which had greater contributions of heat gains in the base case. Therefore, this study aims to be a guideline for evaluating the impact that different passive strategies entail in different climates and their adaptation to existing residential buildings. However, future work should be conducted with the use of different passive design by means of thermal energy performance simulation, to accomplish a 
greater reduction of electricity consumption with the consideration of the thermal balance of the building.

Supplementary Materials: The following are available online at https:/ / www.mdpi.com/article / $10.3390 /$ su13148064/s1. Table S1. Data of the internal gains (occupancy) used to simulate in the software. Table S2. Base-case building operation schedules per room for weekdays. Table S3. Base-case building operation schedules per room for weekends.

Author Contributions: Conceptualization, A.P.V. and L.H.; methodology, A.P.V. and L.H.; software, A.P.V.; validation, A.P.V. and L.H.; formal analysis, A.P.V. and L.H.; investigation, A.P.V. and L.H.; resources, A.P.V.; data curation, A.P.V. and L.H.; writing-original draft preparation, A.P.V. and L.H.; writing-review and editing, A.P.V. and L.H.; visualization, A.P.V. and L.H.; supervision, L.H.; project administration, L.H.; funding acquisition, L.H. Thermal energy performance simulation of a residential building retrofitted with passive design strategies: A case study in Mexico. Both authors have read and agreed to the published version of the manuscript.

Funding: This research was funded by Anahuac México University, Project number INNDIAHABL170215171.

Institutional Review Board Statement: Not applicable.

Informed Consent Statement: Not applicable.

Data Availability Statement: Data is contained within the article.

Acknowledgments: The authors want to thank CONACYT for the scholarship given.

Conflicts of Interest: The authors declare no conflict of interest.

\section{References}

1. Secretaría de Energía (SENER). Balance Nacional de Energía 2018. Available online: https:/ /www.gob.mx/sener/documentos / balance-nacional-de-energia-2018 (accessed on 26 October 2020).

2. International Energy Agency (IEA). Energy Efficiency Market Report 2019. Available online: https:// webstore.iea.org/marketreport-series-energy-efficiency-2019\#: \{\}:text=Energy\%20Efficiency\%202019\%20is\%20the,status\%20of $\% 20$ global $\% 20$ energy $\%$ 20efficiency (accessed on 28 October 2020).

3. Zhan, J.; Liu, W.; Wu, F.; Li, Z.; Wang, C. Life cycle energy consumption and greenhouse gas emissions of urban residential buildings in Guangzhou city. J. Clean. Prod. 2018, 194, 318-326. [CrossRef]

4. International Energy Agency (IEA). Global Energy and CO2 Status Report 2018. Available online: https://iea.blob.core.windows. net/assets/23f9eb39-7493-4722-aced-61433cbffe10/Global_Energy_and_CO2_Status_Report_2018.pdf (accessed on 25 May 2021).

5. U.S. Energy Information Administration (EIA). EIA Projects Nearly 50\% Increase in World Energy Usage by 2050, Led by Growth in Asia.. Available online: https:/ / www.eia.gov / todayinenergy / detail.php?id=41433 (accessed on 25 May 2021).

6. Comisión Económica para América Latina y el Caribe (CEPAL). Informe Nacional de Monitoreo de la Eficiencia Energética de México. 2018. Available online: https://repositorio.cepal.org/bitstream/handle/11362/43612/1/S1800496_es.pdf (accessed on 28 October 2020).

7. Diario Oficial de la Federación (DOF). Acuerdo por el que la Secretaría de Energía Aprueba y Publica la Actualización de la Estrategia de Transición para Promover el Uso de Tecnologías y Combustibles más Limpios, en Términos de la Ley de Transición Energética. Available online: https:/ /www.dof.gob.mx/nota_detalle.php?codigo=5585823\&fecha=07/02/2020 (accessed on 30 October 2020).

8. UN Environment and International Energy Agency. Towards a Zero-Emissions, Efficient and Resilient Buildings and Construction Sector. In 2018 Global Status Report for Buildings and Construction; UN Environment and International Energy Agency: Paris, France, 2019.

9. Comisión Nacional para el Uso Eficiente de la Energía (CONUEE). Análisis de la Evolución del Consumo Eléctrico del Sector Residencial Entre 1982 y 2018 e Impactos de Ahorro de Energía por Políticas Públicas. Cuadernos de la CONUEE, (2). Available online: https://www.gob.mx/cms/uploads/attachment/file/439598/cuaderno2nvociclo_1.pdf (accessed on 2 November 2020).

10. Comisión Nacional para el Uso Eficiente de la Energía (CONUEE). Energía y Edificaciones en México: Importancia y Políticas Públicas Presentes y Futuras. Cuadernos de la CONUEE, (10). Available online: https:/ /www.conuee.gob.mx/transparencia/ boletines/Cuadernos/cuadernoNo.10.pdf (accessed on 2 November 2020).

11. Commission for Environmental Cooperation. Secretariat. In Green Building in North America: Opportunities and Challenges; Commission for Environmental Cooperation: Montreal, QC, Canada, 2008; p. 80.

12. Lucero-Álvarez, J.; Rodríguez-Muñoz, N.A.; Martín-Domínguez, I.R. The Effects of Roof and Wall Insulation on the Energy Costs of Low Income Housing in Mexico. Sustainability 2016, 8, 590. [CrossRef]

13. Mahar, W.A.; Verbeeck, G.; Reiter, S.; Attia, S. Sensitivity Analysis of Passive Design Strategies for Residential Buildings in Cold Semi-Arid Climates. Sustainability 2020, 12, 1091. [CrossRef] 
14. Taleb, H.M. Using passive cooling strategies to improve thermal performance and reduce energy consumption of residential buildings in U.A.E. buildings. Front. Archit. Res. 2014, 3, 154-165. [CrossRef]

15. Bhikhoo, N.; Hashemi, A.; Cruickshank, H. Improving Thermal Comfort of Low-Income Housing in Thailand through Passive Design Strategies. Sustainability 2017, 9, 1440. [CrossRef]

16. Oropeza-Perez, I.; Østergaard, P.A. Energy saving potential of utilizing natural ventilation under warm conditions-A case study of Mexico. Appl. Energy 2014, 130, 20-32. [CrossRef]

17. Bhamare, D.K.; Rathod, M.K.; Banerjee, J. Passive cooling techniques for building and their applicability in different climatic zones-The state of art. Energy Build. 2019, 198, 467-490. [CrossRef]

18. Liu, S.; Kwok, Y.T.; Lau, K.; Ouyang, W.; Ng, E. Effectiveness of passive design strategies in responding to future climate change for residential buildings in hot and humid Hong Kong. Energy Build. 2020, 228, 110469. [CrossRef]

19. Omrany, H.; Marsono, A.K. Optimization of building energy performance through passive design strategies. Br. J. Appl. Sci. Technol. 2017, 13, 1-16. [CrossRef]

20. Gong, X.; Akashi, Y.; Sumiyoshi, D. Optimization of passive design measures for residential buildings in different Chinese areas. Build. Environ. 2012, 58, 46-57. [CrossRef]

21. Cheung, C.K.; Fuller, R.J.; Luther, M.B. Energy-efficient envelope design for high-rise apartments. Energy Build. 2005, 37, 37-48. [CrossRef]

22. Breesch, H.; Janssens, A. Performance Evaluation of Passive Cooling in Office Buildings Based on Uncertainty and Sensitivity Analysis. Sol. Energy 2010, 84, 1453-1467. [CrossRef]

23. Badescu, V.; Cathcart, R.B. Environmental Thermodynamic Limitations on Global Human Population. Int. J. Glob. Energy Issues 2006, 25, 129-140. [CrossRef]

24. Natephra, W.; Motamedi, A.; Yabuki, N.; Fukuda, T. Integrating 4D Thermal Information with BIM for Building Envelope Thermal Performance Analysis and Thermal Comfort Evaluation in Naturally Ventilated Environments. Build. Environ. 2017, 124, 194-208. [CrossRef]

25. Natephra, W.; Yabuki, N.; Fukuda, T. Optimizing the Evaluation of Building Envelope Design for Thermal Performance Using a BIM-Based Overall Thermal Transfer Value Calculation. Build. Environ. 2018, 136, 128-145. [CrossRef]

26. Diario Oficial de la Federación (DOF). Norma Oficial Mexicana NOM-020-ENER-2011, Eficiencia Energética en EdificacionesEnvolvente de Edificios para uso Habitacional. Available online: http:/ /dof.gob.mx/nota_detalle.php?codigo=5203931\&fecha= 09/08/2011 (accessed on 28 October 2020).

27. Organismo Nacional de Normalización y Certificación de la Construcción y Edificación, S.C. (ONNCCE). NMX-C-460-ONNCCE2009 Industria de la Construcción-Aislamiento Térmico-Valor "R" para las Envolventes de Vivienda por Zona Térmica para la República Mexicana-Especificaciones y Verificación. Available online: https:/ / onncce.org.mx/es/?option=com_merchant\& view=category\&cid=34 (accessed on 28 October 2020).

28. Medrano-Gómez, L.E.; Escobedo, A. Social housing retrofit: Improving energy efficiency and thermal comfort for the housing stock recovery in Mexico. Energy Procedia 2017, 121, 41-48. [CrossRef]

29. Martin-Dominguez, I.R.; Rodriguez-Muñoz, N.A.; Romero-Perez, C.K.; Najera-Trejo, M.; Ortega-Avila, N. Analysis of the Methodologic Assumptions of the NOM-020-ENER-2011-Mexican Residential Building Standard. Environments 2018, 5, 118. [CrossRef]

30. Dodge Data \& Analytics. World Green Building Trends 2018. Available online: https://www.worldgbc.org/sites/default/files/ World\%20Green\%20Building\%20Trends\%202018\%20SMR\%20FINAL\%2010-11.pdf (accessed on 30 October 2020).

31. Rocky Mountain Institute (RMI). Building Energy Modeling for Owners and Managers. Available online: https://rmi. org/insight/building-energy-modeling-for-owners-and-managers-a-guide-to-specifying-and-securing-services / (accessed on 30 October 2020).

32. Mecca, U.; Moglia, G.; Piantanida, P.; Prizzon, F.; Rebaudengo, M.; Vottari, A. How energy retrofit maintenance affects residential buildings market value? Sustainability 2020, 12, 5213. [CrossRef]

33. Audenaert, A.; De Cleyn, S.H.; Vankerckhove, B. Economic analysis of passive houses and low-energy houses compared with standard houses. Energy Policy 2008, 36, 47-55. [CrossRef]

34. Instituto Nacional de Estadística y Geografía (INEGI). Housing Units. Available online: https://en.www.inegi.org.mx/temas/ vivienda/\#General_information (accessed on 1 June 2021).

35. Revitaliza Consultores (2018). ¿Qué es el Modelado Energético? Available online: http://revitalizaconsultores.com/blog/2018/0 7/11/modelado-energetico/ (accessed on 30 October 2020).

36. DesignBuilder Software Ltd, DesignBuilder Software Packages. Available online: https: / /designbuilder.co.uk/ (accessed on 30 October 2020).

37. Meteonorm. Meteonorm Software. Available online: https://meteonorm.com/en/ (accessed on 2 November 2020).

38. Sistema Meteorológico Nacional (SMN). Resúmenes Mensuales de Temperaturas y Lluvia 2008 a 2018. Available online: https: //smn.conagua.gob.mx/es / climatologia/temperaturas-y-lluvias/resumenes-mensuales-de-temperaturas-y-lluvias (accessed on 2 November 2020).

39. NASA. Software POWER Project Data Sets. 2018. Available online: https:// power.larc.nasa.gov/ (accessed on 2 November 2020).

40. Instituto Nacional de Estadística y Geografía (INEGI). Principales resultados de la Encuesta Intercensal 2015. Available online: http:/ / internet.contenidos.inegi.org.mx/contenidos/productos/prod_serv/contenidos/espanol/bvinegi/productos/ nueva_estruc/702825078966.pdf (accessed on 26 October 2020). 
41. Autodesk REVIT. Available online: https://www.autodesk.mx/products/revit/overview?term=1-YEAR (accessed on 1 June 2021).

42. Tian, Z.C.; Zhang, X.K.; Jin, X.; Xin, Z.; Si, B.H.; Shi, X. Towards adoption of building energy simulation and optimization for passive building design: A survey and a review. Energy Build. 2018, 158, 1306-1316. [CrossRef]

43. Mohd Nazi, W.I.W.; Royapoor, M.; Wang, Y.; Roskilly, A.P. Office building cooling load reduction using thermal analysis method-A case study. Appl. Energy 2017, 185, 1574-1584. [CrossRef]

44. Nazi, W.I.W.; Wang, Y.D.; Roskilly, T. Methodologies to reduce cooling load using heat balance analysis: A case study in an office building in a Tropical Country. Energy Proced. 2015, 75, 1269-1274. [CrossRef]

45. Royapoor, M.; Roskilly, T. Building model calibration using energy and environmental data. Energy Build. 2015, 94, 109-120. [CrossRef]

46. Roberti, F.; Filippi, U.; Gasparella, A. Calibrating historic building energy models to hourly indoor air and surface temperatures: Methodology and case study. Energy Build. 2015, 108, 236-243. [CrossRef]

47. Tabares-Velasco, P.C.; Christensen, C.; Bianchi, M. Verification and validation of EnergyPlus phase change material model for opaque wall assemblies. Build. Environ. 2012, 54, 186-196. [CrossRef]

48. Kamel, E.; Memari, A.M. Review of BIM's application in energy simulation: Tools, issues, and solutions. Autom. Constr. 2019, 97, 164-180. [CrossRef]

49. Bastos Porsani, G.; Del Valle de Lersundi, K.; Sánchez-Ostiz Gutiérrez, A.; Fernández Bandera, C. Interoperability between Building Information Modelling (BIM) and Building Energy Model (BEM). Appl. Sci. 2021, 11, 2167. [CrossRef]

50. Akbarieh, A. Systematic Investigation of Interoperability Issues between Building Information Modelling and Building Energy Modelling-BIM-Based BEM Information Exchange Issues. Master's Thesis, NTNU, Taipei, Taiwan, 2018.

51. Sanhudo, L.; Ramos, N.M.; Martins, J.P.; Almeida, R.M.; Barreira, E.; Simões, M.L.; Cardoso, V. Building information modeling for energy retrofitting-A review. Renew. Sustain. Energy Rev. 2018, 89, 249-260. [CrossRef]

52. Huanga, H.; Mohd Nazi, W.I.W.; Yua, Y.; Wang, Y. Energy performance of a high-rise residential building retrofitted to passive building standard-A case study. Appl. Therm. Eng. 2020, 181, 115902. [CrossRef]

53. Mustafaraj, G.; Marini, D.; Costa, A.; Keane, M. Model calibration for building energy efficiency simulation. Appl. Energy 2014, 130, 72-85. [CrossRef]

54. Zhou, H.; Mohd Nazi, W.I.W.; Wang, Y.; Roskilly, A. Investigating the impact of building's facade on the building's energy performance-a case study. Energy Proced. 2019, 158, 3144-3151. [CrossRef]

55. Qu, K.; Chen, X.; Wang, Y.; Calautit, J.; Riffat, S.; Cui, X. Comprehensive energy, economic and thermal comfort assessments for the passive energy retrofit of historical buildings-A case study of a late nineteenth-century victorian house renovation in the UK. Energy 2021, 220, 119646. [CrossRef]

56. Trovato, M.R.; Nocera, F.; Giuffrida, S. Life-Cycle Assessment and Monetary Measurements for the Carbon Footprint Reduction of Public Buildings. Sustainability 2020, 12, 3460. [CrossRef]

57. Banco de México (BANXICO). Sistema de Información Económica. Available online: https://www.banxico.org.mx/tipcamb/ main.do?page=tas\&idioma $=$ sp (accessed on 1 June 2021).

58. Diario Oficial de la Federación (DOF). Parámetros de Estimación de Vida Útil. 15 de Agosto de 2012. Available online: http:/ / dof.gob.mx/nota_detalle.php?codigo=5264340\&fecha=15/08/2012 (accessed on 28 October 2020). 